\title{
Current Trends of Essential Trace Elements in Patients with Chronic Liver Diseases
}

\author{
Takashi Himoto $^{1, *}$ and Tsutomu Masaki ${ }^{2}$ \\ 1 Department of Medical Technology, Kagawa Prefectural University of Health Sciences, 281-1, Hara, \\ Mure-Cho, Takamatsu, Kagawa 761-0123, Japan \\ 2 Department of Gastroenterology and Neurology, Kagawa University School of Medicine, Kagawa 761-0123, \\ Japan; tmasaki@med.kagawa-u.ac.jp \\ * Correspondence: himoto@chs.pref.kagawa.jp; Tel.: +81-87-870-1240; Fax: +81-87-870-1202
}

Received: 21 April 2020; Accepted: 29 June 2020; Published: 14 July 2020

check for updates

\begin{abstract}
Essential trace elements play crucial roles in the maintenance of health, since they are involved in many metabolic pathways. A deficiency or an excess of some trace elements, including zinc, selenium, iron, and copper, frequently causes these metabolic disorders such as impaired glucose tolerance and dyslipidemia. The liver largely regulates most of the metabolism of trace elements, and accordingly, an impairment of liver functions can result in numerous metabolic disorders. The administration or depletion of these trace elements can improve such metabolic disorders and liver dysfunction. Recent advances in molecular biological techniques have helped to elucidate the putative mechanisms by which liver disorders evoke metabolic abnormalities that are due to deficiencies or excesses of these trace elements. A genome-wide association study revealed that a genetic polymorphism affected the metabolism of a specific trace element. Gut dysbiosis was also responsible for impairment of the metabolism of a trace element. This review focuses on the current trends of four trace elements in chronic liver diseases, including chronic hepatitis, liver cirrhosis, nonalcoholic fatty liver disease, and autoimmune liver diseases. The novel mechanisms by which the trace elements participated in the pathogenesis of the chronic liver diseases are also mentioned.
\end{abstract}

Keywords: zinc; selenium; copper; iron; chronic hepatitis; liver cirrhosis; nonalcoholic fatty liver disease; autoimmune liver disease; hepatic fibrosis; hepatic steatosis

\section{Introduction}

The liver plays indispensable roles in the maintenance of essential trace elements homeostasis [1,2]. Most of the trace elements are absorbed from the duodenum and/or jejunum and flow out in the portal circulation by binding to the plasma proteins. These trace elements are distributed to the tissues or organs that require them. It is primarily the liver that initiates the synthesis of the proteins bound for several trace elements, including zinc $(\mathrm{Zn})$, selenium $(\mathrm{Se})$, iron $(\mathrm{Fe})$, and copper $(\mathrm{Cu})$ in order to transport or distribute these trace elements. The liver is also involved in the excretion of trace elements such as $\mathrm{Cu}$ and magnesium $(\mathrm{Mg})$, since the liver acts as a producer of bile.

Most of the trace elements that have immunomodulatory and antimicrobial activities generally serve as enzyme-cofactors, antioxidants, and/or anti-inflammatory agents [3]. Impairments of the liver function result in disturbances of the metabolism of trace elements, leading to the initiation of oxidative stress and the subsequent inflammatory and/or fibrotic changes in the liver. The impairment of the homeostasis of trace elements leads to various inflammatory changes and/or metabolic abnormalities such as those observed in inflammatory bowel disease [4], diabetes mellitus [5], dyslipidemia [6], and sarcopenia [7] as well as chronic liver injuries. 
Recent advances in molecular biological techniques have enabled us to elucidate the novel mechanisms by which the impairment of trace elements metabolism causes these metabolic abnormalities. Genetic polymorphisms to regulate the metabolism of some trace elements have been identified. The alteration of gut flora results in disorders of some trace elements metabolism, exacerbating hepatic steatosis and/or fibrosis. Some microRNAs may participate in the metabolism of a trace element.

This review highlights the current trends of four essential trace elements $(\mathrm{Zn}, \mathrm{Se}, \mathrm{Fe}$, and $\mathrm{Cu})$ in chronic liver diseases (CLDs), including chronic hepatitis, liver cirrhosis, nonalcoholic fatty liver disease (NAFLD), and autoimmune liver disease. We also discuss the novel mechanisms by which impairment of the metabolism of trace elements may account for the pathogenesis of these CLDs.

\section{The Roles of Trace Elements}

\subsection{Translation, Transcription, and Replication of Hepatitis Viruses}

Some trace elements are required to evoke an effective immune response to viral infections, whereas other trace elements are involved in the clearance of viruses. The inhibitory roles of these essential trace elements are revealed in the translation, transcription, and replication of hepatitis viruses, including hepatitis B virus (HBV), hepatitis C virus (HCV), and hepatitis E virus (HEV). Se and Zn were demonstrated to suppress the transcription and replication of hepatitis viruses [8,9]. Table 1 shows the function of such trace elements in the translation, transcription, and replication of these viruses.

Table 1. Roles of trace elements in the translation, transcription, and replication of hepatitis viruses.

\begin{tabular}{cclc}
\hline $\begin{array}{c}\text { Hepatitis } \\
\text { Viruses }\end{array}$ & $\begin{array}{c}\text { Trace } \\
\text { Elements }\end{array}$ & \multicolumn{1}{c}{ Function of Trace Element } & References \\
\hline & $\mathrm{Zn}$ & Zn deficiency caused poor response to HBV vaccination & {$[10,11]$} \\
\cline { 2 - 4 } & $\mathrm{Se}$ & $\begin{array}{l}\text { Sodium selenite suppressed HBV protein expression, } \\
\text { transcription, and genome replication }\end{array}$ & {$[11]$} \\
\hline $\mathrm{HBV}$ & $\mathrm{Zn}$ & $\begin{array}{l}\text { negative regulator of HCV replication } \\
\text { initiation of IFN- } \alpha\end{array}$ & {$[12,13]$} \\
& $\mathrm{Se}$ & $\begin{array}{l}\text { intracellular replication of HCV } \\
\text { initiation of selenoprotein P by HCV infection }\end{array}$ & {$[15]$} \\
\cline { 2 - 4 } & $\mathrm{Fe}$ & $\begin{array}{l}\text { promotion/inhibition of HCV replication (controversial) } \\
\text { promotion of HCV translation }\end{array}$ & {$[17,18]$} \\
\cline { 2 - 4 } & $\mathrm{Cu}$ & Cuprous oxide inhibited the entry of HCV pseudoparticle & {$[19,20]$} \\
\hline $\mathrm{HEV}$ & $\mathrm{Zn}$ & $\begin{array}{l}\text { Zinc sulfate and zinc acetate inhibited the activity of viral } \\
\text { RNA-dependent RNA polymerase }\end{array}$ & {$[22]$} \\
\hline
\end{tabular}

HBV: Hepatitis B virus; HCV: Hepatitis C virus; HEV: Hepatitis E virus; Zn: Zinc; Se: Selenium; Fe: Iron; Cu: Copper; IFN: Interferon.

\subsubsection{HBV}

HBV is a member of the Hepadnaviridae family and has circular and partially double-stranded DNA. A persistent HBV infection causes major public health problems throughout the world, especially in East Asia and Africa [23]. Individuals who are infected with HBV can develop chronic liver disease, including chronic hepatitis and liver cirrhosis, and subsequently hepatocellular carcinoma (HCC).

The $\mathrm{Zn}$ status determined the responsiveness to HBV vaccination. The responsiveness was evaluated by the serum anti-HBs level. The serum anti-HBs level was markedly decreased in rats fed a diet with lower $\mathrm{Zn}$ content [10]. The poor response to HBV vaccination in such rodents may be derived from suppressed T-lymphocyte proliferation due to Zn deficiency. Zn deficiency affects both the innate and adaptive immune systems, leading to the impaired activation and maturation of lymphocytes [24]. Likewise, gestational Zn deficiency in a murine model resulted in weaker responsiveness to HBV 
vaccination in offspring mice because of the decreased number of B cells and impaired HBV-specific IgG production [11].

In contrast, Cheng et al. demonstrated that sodium selenite suppressed HBV protein expression, transcription, and genome replication, using the human hepatoma cell lines [25]. Se is likely to activate p53 by promoting its expression and phosphorylating multiple sites, and suppressing the activities of HBV promoters and enhancers.

\subsection{2. $\mathrm{HCV}$}

$\mathrm{HCV}$ is a positive-polarity, single-stranded RNA virus that belongs to the Flaviviridae family. HCV infects hepatocytes and is usually transmitted through exposure to infected body fluids, including blood transfusions and drug abuse. Chronic HCV infection is thought to cause the production of reactive oxygen species (ROS) and subsequently inflammation and fibrosis in the liver, leading to chronic hepatitis, liver cirrhosis, and ultimately to HCC [26]. A persistent HCV infection also results in various metabolic abnormalities such as insulin resistance, hepatic steatosis, dyslipidemia, and Fe overload [27].

A large amount of evidence obtained over the past decades indicates that $Z n$ plays suppressive roles in the replication of HCV. Yuasa et al. demonstrated that $\mathrm{Zn}$ salts acted as a negative regulator of the virus replication in genome-length HCV RNA-replicating cells [12]. The authors speculated that Zn might affect the NS2 or NS3 protein and consequently inhibit the replication of genome-length HCV RNA. In later studies, the N2/3 auto-cleavage activity and NS3 protease activity were both confirmed to be Zn-dependent [28], which seems to be plausible because NS3 protease is one of the Zn-containing enzymes [29].

It is of interest that zinc sulfate can reduce the HCV replication in vitro [13]. However, this effect of zinc sulfate was reduced when metallothionein (MT) genes were knocked out [13], suggesting that MTs are either directly antiviral by sequestering Zn away from viral MTs such as NS5 [30], or indirectly antiviral by acting as $\mathrm{Zn}$ chaperones and facilitating antiviral signaling [31]. It is reasonable that serum $\mathrm{Zn}$ levels in patients with HCV-related CLD were increased by treatment with direct-acting antiviral agents (DAAs) [32]. Read et al. recently elucidated that a single-nucleotide polymorphism of interferon-lambda 3 (IFN- $\lambda 3$ ), which is one of the antiviral and pro-inflammatory cytokines, was correlated with increased hepatic MT expression through increased systemic Zn levels [14].

A decline in the systemic Se concentration may be attributable to an intracellular replication of HCV. RNA viruses, including HCV and human immunodeficiency virus (HIV), encode a Se-dependent glutathione peroxidase (GPx) module [15], which is one of the selenoproteins and protects against damage induced by free radicals. It is plausible that serum Se levels were negatively correlated with the loads of HCV RNA in patients with chronic hepatitis C [33], but our previous study did not confirm this phenomenon in patients with HCV-related CLD [34]. The decrease in a circulating Se concentration may also reflect a systemic inflammatory response [35]. Notably, Murai et al. demonstrated that the hepatic selenoprotein P mRNA was upregulated by an HCV infection, and that its knockout in hepatocytes caused an induction of IFN-stimulated genes and a subsequently inhibited the replication of HCV [16].

It remains controversial whether Fe enhances the replication of HCV [17,18]. However, Fe proved to facilitate the translation of HCV by stimulating the expression of eukaryotic initiation factor $3 \mathrm{~A}$ (elF3A) [19]. The expression of hepcidin, a negative regulator of $\mathrm{Fe}$, was suppressed in HCV-infected cells [36]. This suppressive effect may be regulated by histone acetylation. Foka et al. also documented that the overexpression of hepcidin antimicrobial peptide (HAMP) promoted the translation of HCV in vitro [20].

No evidence has been accumulated showing that $\mathrm{Cu}$ plays a crucial role in the translation or replication of HCV. However, cuprous oxide, a variant form of $\mathrm{Cu}$, is likely to inhibit the entry of $\mathrm{HCV}$ pseudoparticles into hepatic cells without any effect on the replication of HCV [21]. Metallopeptide 
Cu-GGHYrFK, which targets stem loop IV (SLIV) of the HCV internal ribosome entry site (IRES) is expected to become a distinct therapeutic agent for the treatment of an HCV infection [37].

\subsubsection{HEV}

HEV is a single-stranded RNA virus that belongs to the Hepeviridae family. Acute hepatitis caused by an HEV infection is usually self-limiting in healthy subjects. However, a persistent HEV infection can progress to chronic hepatitis or even to liver cirrhosis in immunocompromised individuals [38].

It was recently elucidated that $\mathrm{Zn}$ salts (zinc sulfate and zinc acetate) directly inhibited the activity of viral RNA-dependent RNA polymerase, leading to the inhibition of an HEV replication [22]. In addition, a nonstructural HEV protein was currently identified as a putative Zn-binding protein [39].

\subsection{The Roles of Trace Elements in Hepatic Inflammation}

\subsection{1. $\mathrm{Zn}$}

$\mathrm{Zn}$ is widely known to have cytoprotective properties against oxidative stress, apoptosis, and inflammation [40-42]. Zn deficiency thus causes the production of ROS, and subsequently leads to inflammation in the liver (Figure 1). Zn deficiency is often observed in patients with chronic hepatitis [33,43-50] or in those with NAFLD [51] (Table 2), although a lower Zn concentration does not necessarily correspond to the inflammation process [2]. The serum Zn levels of patients with chronic hepatitis were inversely correlated with serum transaminase levels [47] and with their histological activity scores [45].

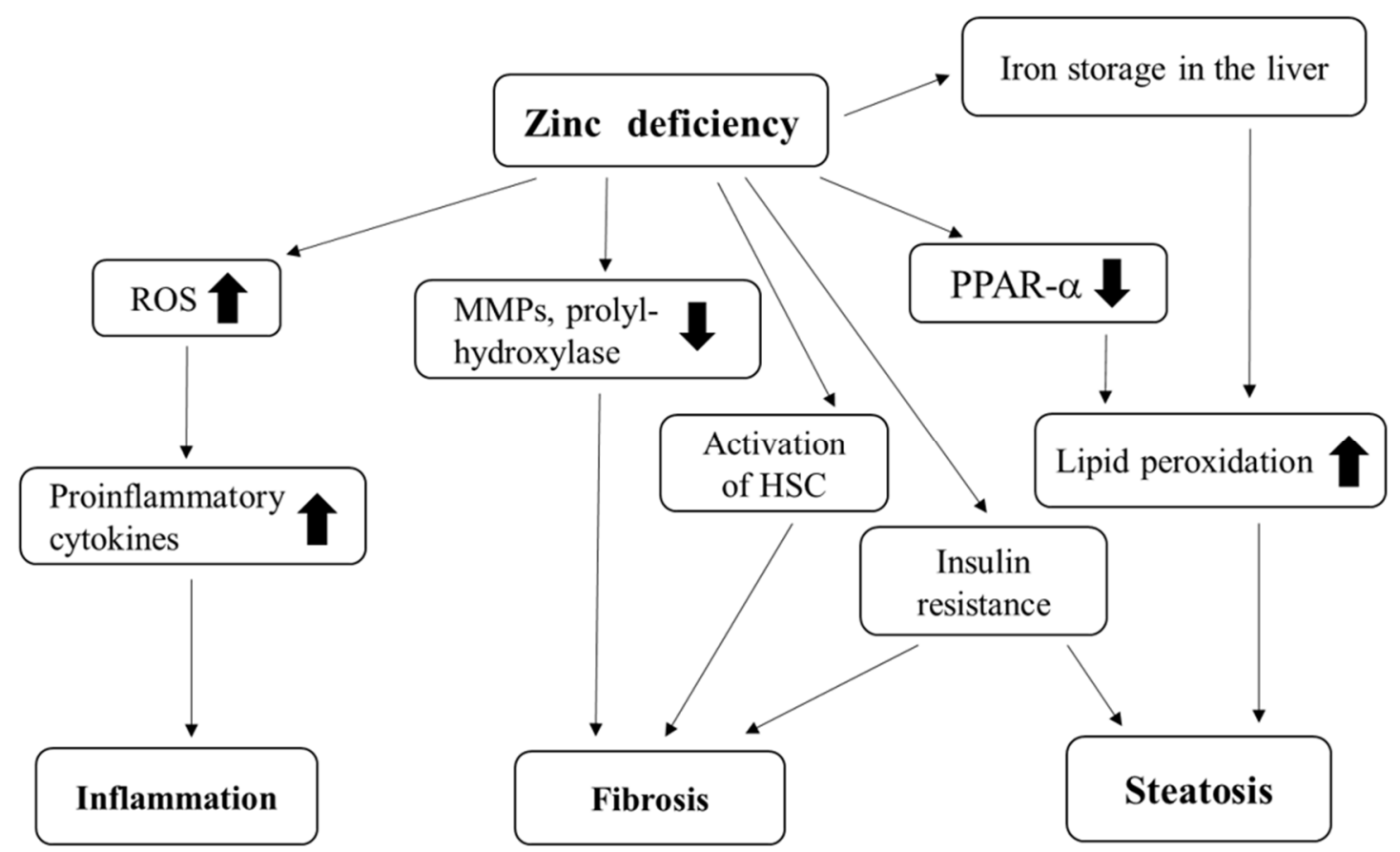

Figure 1. Relationship between zinc deficiency and inflammation, fibrosis or steatosis in the liver. ROS: Reactive oxygen species; MMP: Metalloproteinase; PPAR $\alpha$ : Peroxisome proliferator-activated receptor- $\alpha$; HSC: Hepatic stellate cell; $\mathbf{\uparrow}$ : Promotion; $\downarrow$ : Inhibition.

Zn supplementation has a favorable effect on hepatic inflammation in such patients. Our previous study revealed that the additional administration of polaprezinc ( $225 \mathrm{mg} /$ day for six months), a complex of $\mathrm{Zn}$ and L-carnosine, improved serum transaminase levels in patients with HCV-related CLD, including chronic hepatitis and liver cirrhosis, by attenuating hepatic Fe storage [67] (Table 3). Matsumura et al. also confirmed the effect of polaprezinc $(150 \mathrm{mg} /$ day for three years) on hepatic inflammation in patients with chronic hepatitis C [68]. Zn is also administered as an antioxidant 
adjuvant to IFN in patients with chronic hepatitis $\mathrm{C}$. The combination treatment of IFN with antioxidants, including Zn [69-71] and N-acetylcysteine, sodium selenite, and vitamin E [72] had promising results in such patients, although a meta-analysis did not demonstrate the beneficial effects by administration of $\mathrm{Zn}$ [73].

Table 2. Comparisons of the status of trace elements between HCV-related CLD and NAFLD/NASH.

\begin{tabular}{ccc}
\hline Trace Elements & HCV-Related CLD & NAFLD/NASH \\
\hline \multirow{2}{*}{ Zn } & low & low \\
& {$[46-50]$} & {$[51-53]$} \\
\hline \multirow{2}{*}{ Se or GPx } & low & high \\
& {$[33,34,54,55]$} & {$[56,57]$} \\
\hline \multirow{2}{*}{ Fe (ferritin) } & high & high \\
& {$[48,58,59]$} & {$[60,61]$} \\
\hline \multirow{2}{*}{ hepcidin } & low & high \\
& {$[62]$} & {$[63]$} \\
\hline \multirow{2}{*}{ Cu } & high & low \\
& {$[33,46,64]$} & {$[65]$} \\
\hline \multirow{2}{*}{ ceruloplasmin } & unknown & low \\
& & {$[66]$}
\end{tabular}

HCV: Hepatitis C virus; NAFLD: Nonalcoholic fatty liver disease; NASH: Nonalcoholic steatohepatitis; Zn: Zinc; Se: Selenium; Fe: Iron; $\mathrm{Cu}$ : Copper.

Table 3. Summary of the clinical trials on administration or depletion of the trace elements in patients with CLDs.

\begin{tabular}{|c|c|c|c|c|}
\hline Trace Elements & $\begin{array}{l}\text { Formulations } \\
\text { and Dosages }\end{array}$ & $\begin{array}{l}\text { Assigned } \\
\text { Patients }\end{array}$ & Effects by Trace Elements & References \\
\hline \multirow{4}{*}{$\mathrm{Zn}$} & \multirow{2}{*}{$\begin{array}{l}\text { polaprezinc, } \\
225 \mathrm{mg}\end{array}$} & \multirow{2}{*}{$\begin{array}{l}\text { chronic } \\
\text { hepatitis C }\end{array}$} & improvement of serum ALT level & {$[67,68]$} \\
\hline & & & improvement of serum ferritin level & [67] \\
\hline & $\begin{array}{l}\text { polaprezinc, } \\
150 \mathrm{mg}\end{array}$ & \multirow[t]{2}{*}{$\begin{array}{l}\text { liver } \\
\text { cirrhosis }\end{array}$} & attenuation of hepatic fibrosis & [74] \\
\hline & $\begin{array}{l}\text { zinc sulfate, } \\
50 \mathrm{mg}\end{array}$ & & $\begin{array}{l}\text { prevention of present clinical status } \\
\text { deterioration }\end{array}$ & [75] \\
\hline \multirow{3}{*}{$\begin{array}{l}\text { IFN-based treatment } \\
\text { combined with Zn }\end{array}$} & \multirow{3}{*}{$\begin{array}{l}\text { polaprezinc, } \\
150 \mathrm{mg}\end{array}$} & \multirow{3}{*}{$\begin{array}{l}\text { chronic } \\
\text { hepatitis C }\end{array}$} & $\begin{array}{l}\text { higher CR rate than the treatment } \\
\text { with IFN alone }\end{array}$ & [69] \\
\hline & & & $\begin{array}{l}\text { lower ALT levels than the treatment } \\
\text { with IFN alone }\end{array}$ & [70] \\
\hline & & & $\begin{array}{l}\text { lower incident of gastrointestinal } \\
\text { adverse effects }\end{array}$ & [71] \\
\hline \multirow{2}{*}{ Se } & $\begin{array}{l}\text { selenite, } \\
200 \text { or } 400 \mu \mathrm{g}\end{array}$ & $\begin{array}{l}\text { liver } \\
\text { cirrhosis }\end{array}$ & improvement of hepatic reserve & [76] \\
\hline & $\begin{array}{l}200 \mu \mathrm{g} \\
\text { selenium }\end{array}$ & PBC & insignificant & [77] \\
\hline $\begin{array}{l}\text { combined treatment of } \\
\text { ascorbic acid and } \\
\alpha \text {-tocophenol with Se }\end{array}$ & $\begin{array}{l}200 \mu \mathrm{g} \\
\text { selenium }\end{array}$ & $\begin{array}{l}\text { chronic } \\
\text { hepatitis C }\end{array}$ & insignificant & [78] \\
\hline \multirow{2}{*}{$\begin{array}{l}\text { Fe depletion } \\
\text { (phlebotomy) }\end{array}$} & & $\begin{array}{l}\text { chronic } \\
\text { hepatitis C }\end{array}$ & $\begin{array}{l}\text { improvement of serum ALT level } \\
\text { improvement of serum ferritin level } \\
\text { improvement of hepatic fibrosis }\end{array}$ & $\begin{array}{c}{[79,80]} \\
{[79,80]} \\
{[80]}\end{array}$ \\
\hline & & NAFLD & $\begin{array}{l}\text { improvement of serum ALT level } \\
\text { improvement of serum ferritin level } \\
\text { improvement of hepatic fibrosis } \\
\text { improvement of hepatic steatosis }\end{array}$ & $\begin{array}{c}{[81,82]} \\
{[81,82]} \\
{[81]} \\
{[81,82]}\end{array}$ \\
\hline
\end{tabular}

Zn: Zinc; Se: Selenium; Fe: Iron; IFN: Interferon; PBC: Primary biliary cholangitis; NAFLD: Nonalcoholic fatty liver disease; ALT: Alanine aminotransferase; CR: Complete response. 


\subsubsection{Se}

Se is a constituent of GPx which protects against the damage induced by ROS $[9,83]$. Reduced serum Se levels are frequently observed in patients with chronic hepatitis $[34,44,48,50,54,55,84-86]$. Serum GPx levels were also lower in patients with chronic hepatitis $C$ than those in cases of a normal healthy control $[17,78,87]$ (Table 2). However, we did not find an inverse correlation between the serum Se and alanine aminotransferase (ALT) level in patients with HCV-related CLD [34]. It is of interest that a Zn transporter, ZIP 8 was associated with Se homeostasis, and that a decrease in the ZIP 8 activity due to Se deficiency potentially evoked liver injury [86].

The effects of Se administration on hepatic inflammation were examined in diabetic rats fed a Zn-deficient diet. The Se supplementation (sodium selenite $0.5 \mathrm{mg} / \mathrm{kg}$ body weight) ameliorated serum ALT levels in those rats fed a Zn-deficiency diet [88]. Interestingly, the Se supplementation in that study modulated the $\mathrm{Zn}$ level in the experimental model. The Se treatment may initiate an increase in insulin activity, and may subsequently improve $\mathrm{Zn}$ deficiency in the experimental model. In fact, we found a positive correlation between the serum $\mathrm{Zn}$ and Se levels in patients with HCV-related CLD [34]. Another study revealed that the Se-enriched lactobacillus reversed $\mathrm{CCl}_{4}$-induced liver injury by facilitating antioxidant enzyme activity and inhibiting lipid peroxidase activity [87]. Unfortunately, beneficial effects of antioxidants, including Se, ascorbic acid, and $\alpha$-tocopherol, on serum transaminase levels and HCV RNA load were not apparent in a clinical trial [78].

\subsection{3. $\mathrm{Fe}$}

It is well established that Fe deposition in the liver can initiate ROS and subsequently lead to hepatic inflammation, lipid peroxidation, and insulin resistance [58]. The Fe overload is commonly observed in patients with HCV-related CLD or those with NAFLD, which is characterized by excessive hepatic fat accumulation and no history of alcohol abuse [60] (Table 2) as well as those with hereditary hemochromatosis [89]. We confirmed that serum ferritin levels were closely associated with ALT levels in patients with HCV-related CLD, indicating that the Fe deposit in the liver might evoke hepatic inflammation [48]. In patients with chronic hepatitis $C$, attenuation of the Fe overload by phlebotomy, which is usually performed as a treatment for hemochromatosis, eventually caused the decline of serum transaminase levels $[79,80]$ as well as those with NAFLD [81,82] (Table 3).

Iron regulatory factors, such as hepcidin, ferroportin, and transferrin receptor, also play crucial roles in iron homeostasis. Thus, dysregulation of these factors can initiate Fe storage in the liver. Hepcidin is a peptide hormone produced by the liver that binds to ferroportin and inhibits Fe absorption from the small intestine [90]. The expression of hepcidin was suppressed by HCV-induced oxidative stress in an in vitro study [62]. In contrast, serum hepcidin levels were elevated in patients with NAFLD [63] (Table 2).

\subsection{4. $\mathrm{Cu}$}

$\mathrm{Cu}$ is also another essential trace element that participates in many enzymatic and redox reactions. The circulating $\mathrm{Cu}$ concentration was frequently elevated in patients with chronic hepatitis C $[33,44,46,50,64]$ (Table 2). Increased Cu levels may be derived from the facilitation of ceruloplasmin synthesis by interleukin (IL)- 1 in Cu deficient rats [91]. Ceruloplasmin, a transporter for $\mathrm{Cu}$, is a glycoprotein which is synthesized in the liver, and plays an essential role in the acute-phase reaction [92]. Indeed, serum ceruloplasmin levels were significantly associated with ballooning hepatocytes, inflammatory cells infiltration, and/or hepatic steatosis in pediatric NAFLD patients [66].

The elevated $\mathrm{Cu}$ and ceruloplasmin levels may contribute to the inflammatory change in the liver of patients with chronic hepatitis. The Cu-induced MT also may account for the increase of serum $\mathrm{Cu}$ level in patients with chronic hepatitis $\mathrm{C}$. Excessive $\mathrm{Cu}$ is considered to be related to the induction of MT. The Cu-induced MT probably initiates hydroxyl radicals and subsequently leads to the inflammation in the liver [93]. 
However, the co-administration of $\mathrm{Cu}$ and imatinib mesylate, a tyrosine kinase inhibitor, exhibited the anti-inflammatory and anti-fibrotic effects in HCC-induced rats [94]. These effects may be derived from an anti-inflammatory action of $\mathrm{Cu}$ by suppressing the activity of the protein complex, nuclear factor kappa-light-chain-enhancer of activated B cells (NF-kB).

\subsection{The Roles of Trace Elements in Hepatic Fibrosis}

\subsection{1. $\mathrm{Zn}$}

Zn directly inhibits the fibrotic process in the liver via the actions of metalloproteinase (MMP) or prolyl-hydroxylase $[95,96]$ (Figure 1). Zn also inhibits fibrosis via its anti-inflammatory, anti-apoptotic, and antioxidant properties, or by controlling the function of hepatic stellate cells (HSCs) [97]. Zn deficiency thus participates in hepatic fibrosis both directly and indirectly.

An interesting study documented the improvement of hepatic fibrosis by administration of polaprezinc in vitro [98] and in vivo [99] studies. Polaprezinc supplementation ( $2.2 \mathrm{~g} / \mathrm{kg}$ weight) led to the improvement of hepatic fibrosis in an animal NASH model by promoting fibrolysis via the inhibition of the tissue inhibitor of metalloproteinase (TIMP)-1 activity and by reducing the activity of HSCs [99]. Kono et al. also confirmed the inhibitory effects of polaprezinc $(200 \mathrm{mg} / \mathrm{kg}$ weight/day) on hepatic fibrosis in a rat model of thioacetamide-induced hepatic fibrosis [100]. The effect of zinc oxide nanoparticle $(10 \mathrm{mg} / \mathrm{kg}$ weight/day) on hepatic fibrosis was also demonstrated in rats [101].

A clinical trial revealed that the administration of polaprezinc $(150 \mathrm{mg} /$ day for six months) reduced the type IV collagen levels and the TIMP-1 activity in the sera of patients with liver cirrhosis [74] (Table 3). Another study documented that a low dose of zinc sulfate (50 $\mathrm{mg} \mathrm{Zn} /$ day) can prevent the deterioration of clinical status and suppress excessive $\mathrm{Cu}$ accumulation in non-alcoholic cirrhotic patients [75]. On the contrary, a larger amount of $\mathrm{Zn}$ administration results in severe $\mathrm{Cu}$ deficiency [102].

\subsubsection{Se}

A decline in the serum Se level is frequently observed in patients with liver cirrhosis $[103,104]$, because Se is transported into the blood by binding to Se-containing proteins such as albumin and selenoprotein P [83]. However, the decrease in the serum Se level indicates hepatic dysfunction rather than Se deficiency in such patients [103]. We demonstrated that serum Se levels were reduced in proportion to the severity of hepatic fibrosis in patients with an HCV-related CLD [34]. In another study, the circulating and hepatic Se concentrations were markedly decreased in N-nitrosodimethylamine-induced hepatic fibrosis [105]. In this animal model of hepatic fibrosis, decreases in Se and GPx levels may participate in the impairment of an antioxidant defense, and may trigger the process of hepatic fibrosis.

Ding et al. elucidated that the administration of sodium selenite $(200 \mu \mathrm{g} / \mathrm{kg}$ weight body diet $)$ inhibited hepatic fibrosis in mice by suppressing the number of collagen producing HSCs and by promoting collagen degradation [106]. In the clinical trial, the efficacy of selenite (200 or $400 \mu \mathrm{g} / \mathrm{day})$ was revealed in patients with liver cirrhosis [76]. Further investigations should be required to clarify the inhibitory effect of Se supplementation against hepatic fibrosis in a clinical trial.

\subsubsection{Fe}

The Fe overload facilitates hepatic fibrosis in patients with HCV-related CLD, NASH, alcoholic liver disease, or hemochromatosis [107]. Excessive Fe can initiate the Fenton reaction to generate a large amount of free radicals, subsequently leading to tissue damage in the liver, and finally contributing to hepatic fibrosis. In addition, excessive Fe can promote the signals for fibrosis in parenchymal and non-parenchymal cells.

Several studies have demonstrated that the hepatic Fe accumulation was associated with the severity of hepatic fibrosis in patients with HCV-related CLD $[108,109]$. Phlebotomy resulted in the improvement of the hepatic fibrosis as well as hepatic inflammation in patients with chronic 
hepatitis C [80] (Table 3). Likewise, Fe deposits in the liver may reflect the degree of hepatic fibrosis in patients with NAFLD. Indeed, an increase in the serum ferritin level is closely associated with hepatic Fe deposition, suggesting that the serum ferritin level can be a surrogate marker for hepatic Fe deposition [107]. Therefore, higher serum ferritin levels could be used to predict more advanced fibrosis in such patients [61]. In contrast, Fe depletion by phlebotomy appeared to ameliorate hepatic fibrosis in patients with NAFLD [82] (Table 3).

The serum ferritin level can predict even early mortality in patients with decompensated liver cirrhosis [110]. Similarly, the serum ferritin levels of patients with liver cirrhosis were further increased as the patients' hepatic reserve deteriorated severely [111].

\subsection{4. $\mathrm{Cu}$}

The circulating $\mathrm{Cu}$ concentration is also elevated in proportion to the severity of hepatic fibrosis [112]. $\mathrm{Cu}$ acts as a cofactor against hepatic fibrosis in chronic liver disease, particularly in the biosynthesis of collagen.

The $\mathrm{Cu} / \mathrm{Zn}$ ratio was markedly elevated in patients with liver cirrhosis, compared to that of patients with chronic hepatitis or normal healthy controls [113-115]. It is of interest that a higher $\mathrm{Cu} / \mathrm{Zn}$ ratio was associated with mortality in those patients [113].

In male HBV-related cirrhotic patients, serum ceruloplasmin levels were inversely correlated with hepatic fibrosis, because ceruloplasmin is synthesized in the liver [116]. Likewise, HCV-related cirrhotic patients with hepatic encephalopathy had lower ceruloplasmin concentrations in their sera than those without hepatic encephalopathy and normal healthy subjects [117].

\subsection{The Roles of Trace Elements in Hepatic Steatosis}

\subsection{1. $\mathrm{Zn}$}

$\mathrm{Zn}$ is involved in the activation of peroxisome proliferator-activated receptor- $\alpha$ (PPAR- $\alpha$ ), a regulator of lipid homeostasis [118]. Zn may participate in the DNA-binding activity of PPAR- $\alpha$. Therefore, Zn deficiency may result in a reduction of PPAR- $\alpha$ activity, and consequently the promotion of lipid peroxidation, finally leading to the deterioration of hepatic steatosis (Figure 1).

Indeed, compared to normal control rats, the serum $\mathrm{Zn}$ levels and hepatic $\mathrm{Zn}$ contents were significantly lower in an experimental animal model of fatty liver, which was induced by tetracyclin [119]. We verified the correlation between $\mathrm{Zn}$ deficiency and hepatic steatosis in patients with HCV-related CLD, because hepatic steatosis is one of the common histological features in the liver of those patients [120]. The serum Zn levels of patients gradually decreased as their hepatic steatosis developed from a mild status to a severe status, based on the criteria for hepatic steatosis proposed by Brunt et al. [121], for patients with HCV-related CLD [59]. Approximately equivalent results were obtained from the study by Guo et al.: Serum Zn levels were significantly lower in patients with both chronic hepatitis $C$ and NAFLD compared to patients with chronic hepatitis $C$ alone [50].

It is also well-known that insulin resistance contributes to the process of hepatic steatosis in patients with HCV-related CLD [122]. Our previous study confirmed a close correlation between the severity of hepatic steatosis and the value of a homeostasis model for assessment of insulin resistance (HOMA-IR), an indicator of insulin resistance in such patients [59]. Moreover, our previous studies revealed that serum $\mathrm{Zn}$ levels were inversely correlated with the values of HOMA-IR, suggesting that $\mathrm{Zn}$ deficiency results in the development of insulin resistance in patients with HCV-related CLD [48,59].

Likewise, a recent report by Asprouli et al. documented that serum $\mathrm{Zn}$ levels were also decreased in proportion to the grade of hepatic steatosis in NAFLD patients [52]. Serum Zn levels were inversely correlated with HOMA-IR values in those patients [53]. A lower dietary intake of Zn may account for Zn deficiency in NAFLD patients [123]. It is of interest that the administration of zinc sulfate reversed ethanol-induced hepatic steatosis in mice by reactivating PPAR- $\alpha$ and hepatocyte nuclear factor- $4 \alpha[124]$. 


\subsubsection{Se}

The serum Se levels of patients with both chronic hepatitis $C$ and NAFLD were also lower than those of patients with chronic hepatitis C alone [50]. However, the serum Se levels of NAFLD patients gradually rose as their hepatic steatosis progressed to a severe status [56] (Table 2). Serum GPx levels were also elevated in those patients [57]. The putative mechanism by which Se contributes to the progression of hepatic steatosis in NAFLD has not been fully established. Insulin resistance via the activation of a selenoprotein may account for these phenomena in NAFLD patients. In fact, the serum Se levels were positively correlated with the values of HOMA-IR in patients with NAFLD patients [56]. Misu et al. elucidated the positive correlation between selenoprotein P mRNA levels and the severity of insulin resistance in patients with type 2 diabetes mellitus [125]. Further analyses are necessary to clarify the relationship between serum Se levels and hepatic steatosis in NAFLD patients.

\subsection{3. $\mathrm{Fe}$}

When the transgenic mice expressing the HCV polyprotein were fed an excessive Fe diet, the development of hepatic steatosis was observed through activation of the unfold protein [126]. Our previous study confirmed that serum ferritin levels were increased in proportion to the grade of hepatic steatosis in patients with HCV-related CLD [59]. In the experimental animal model of NAFLD, the hepatic Fe overload was induced prior to the development of hepatic steatosis and insulin resistance [127]. The association of a hepatic Fe deposit with hepatic steatosis was also shown in patients with NAFLD [61]. Indeed, phlebotomy turned out to attenuate hepatic steatosis in those patients $[80,81]$ (Table 3).

\subsection{4. $\mathrm{Cu}$}

The serum $\mathrm{Cu}$ levels of individuals with NAFLD were often decreased [128] (Table 2). Inadequate $\mathrm{Cu}$ availability is likely to increase lipid accumulation in the liver. Thus, lower $\mathrm{Cu}$ bioavailability may affect lipid metabolism and it may be involved in the development of NAFLD [65]. Moreover, $\mathrm{Cu}$ deficiency can initiate the alteration of mitochondrial morphology, leading to an impairment of fatty acid $\beta$ oxidation. These phenomena can affect hepatic lipid accumulation in patients with NAFLD (Figure 2).

It is noteworthy that circulating ceruloplasmin levels were also reduced in NAFLD patients [66]. However, chronic hepatitis B patients with hepatic steatosis had higher ceruloplasmin levels in their sera than those without steatosis. Moreover, serum ceruloplasmin levels were associated with the severity of hepatic steatosis in patients with chronic hepatitis B [129].

$\mathrm{Cu}$ seems to play an important role in the Fe homeostasis and be associated with the Fe perturbation observed in NAFLD [63]. $\mathrm{Cu}$ is required for the function of ceruloplasmin to export Fe from the liver or the reticuloendothelial system, and for the expression of ferroportin. The membrane-bound type of ceruloplasmin might be mandatory for the stability of ferroportin. Consequently, a lower hepatic $\mathrm{Cu}$ content and a lower serum $\mathrm{Cu}$ concentration eventually cause the Fe overload in patients with NAFLD.

A high fructose diet and $\mathrm{Cu}$ restriction may trigger hepatic steatosis and inflammation in mice [130], because dietary fructose inhibits the duodenal $\mathrm{Cu}$ absorption by suppressing duodenal expression of copper transporter-1 (ctr-1) [131], which may be the primary protein responsible for the import of dietary $\mathrm{Cu}$.

Hepatic steatosis is frequently observed in patients with Wilson's disease [132], which is the autosomal recessive hereditary disease, and is caused by the gene mutation of ATP7B essential in the $\mathrm{Cu}$ metabolism [133]. This mutation results in an impaired hepatic $\mathrm{Cu}$ excretion and subsequently $\mathrm{Cu}$ accumulation in the liver. Liggi et al. elucidated the close correlation between the serum $\mathrm{Cu}$ level and grading of hepatic steatosis in those patients, indicating that hepatic steatosis in Wilson's disease may not be derived from metabolic comorbidities but from $\mathrm{Cu}$ accumulation in the liver [134]. 


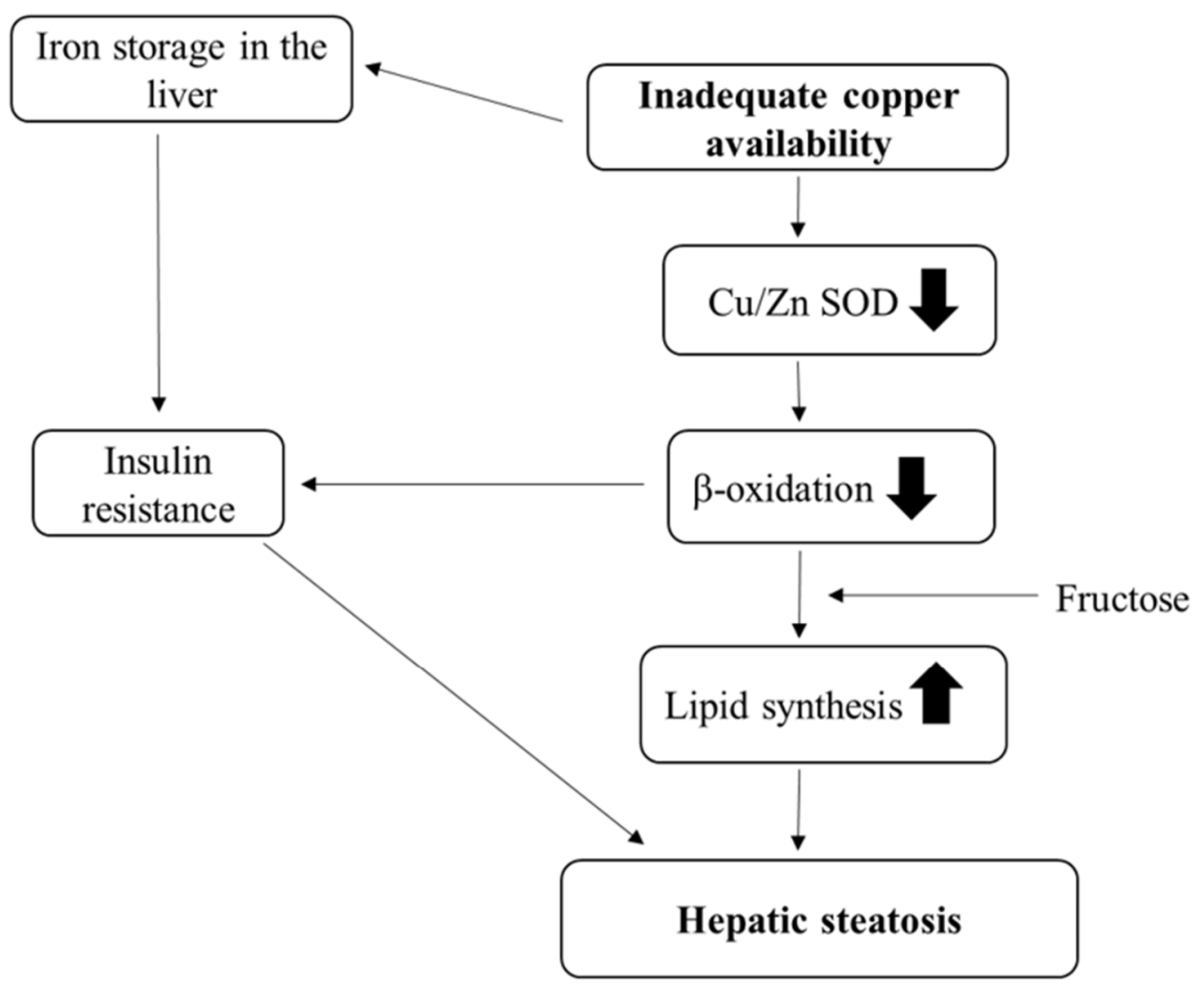

Figure 2. Putative mechanisms by which inadequate copper availability causes hepatic steatosis. SOD: Superoxide dismutase; $\mathbf{1}$ : Promotion; $\downarrow$ : Inhibition.

\subsection{Roles of Trace Elements in Autoimmune Liver Diseases}

\subsection{1. $\mathrm{AIH}$}

Several research groups explored the serum ferritin levels in patients with autoimmune hepatitis (AIH). AIH is largely a chronic necroinflammatory disease of the liver, characterized by hypergammaglobulinemia and circulating autoantibodies [135]. According to a recent study, hyperferritinemia was commonly observed in AIH patients at baseline [136]. Ferritin is an acute-phase reactant, and an increase in the serum ferritin level may reflect the promotion of pro-inflammatory cytokines such as IL-6 in such patients [137]. The serum ferritin levels were thus significantly correlated with serum ALT levels in those patients. The study's authors also revealed that higher levels of serum ferritin and lower levels of serum IgG at baseline could predict more favorable responses to immunosuppressive treatments [136]. Notably, hyperferritinemia in AIH patients with a biochemical response seemed to be independent of the serum hepcidin level. In addition, the severity of Fe deposit in the liver did not affect a response to the treatment at all [136].

Another study revealed that serum ferritin levels were lower in patients with AIH than in patients with chronic hepatitis B, and that the serum hepcidin levels were far lower in patients with AIH than in patients with chronic hepatitis B [138]. Hepcidin is recognized as a chemotactic factor for T-lymphocytes, dendritic cells, monocytes, and mast cells. A decrease in the synthesis of hepcidin may cause an imperfect interplay between the innate and adaptive immune systems in patients with AIH.

Declines in the serum Zn [139] and Se [140] levels of patients with AIH have been reported. Indeed, lower serum $\mathrm{Zn}$ and Se levels were one of the common features in autoimmune diseases [141,142]. However, lower serum $\mathrm{Zn}$ and Se levels in $\mathrm{AIH}$ patients may reflect a consequence of chronic liver damage rather than an autoimmune phenomenon. 


\subsection{2. $\mathrm{PBC}$}

Primary biliary cholangitis (PBC) is an autoimmune cholestatic liver disease characterized by nonsuppurative inflammatory destruction of the interlobular bile ducts [143]. It is well established that cholestasis causes $\mathrm{Cu}$ accumulation in the liver. Orcein stain, which indicates the existence of copper-associated protein, was frequently useful for the diagnosis of PBC [144]. PBC patients positive for the orcein stain in the liver specimens had higher total bilirubin and alkaline phosphatase levels than those negative for the orcein stain [145]. In addition, the serum Zn level of PBC patients gradually decreased as the clinical stage became more severe [146].

The serum Se level was also decreased in patients with PBC [147]. The decline in the serum Se level in PBC patients may be the consequence of chronic liver damage rather than Se deficiency [103]. Indeed, Se supplementation did not affect the liver function of PBC patients [77] (Table 3).

\subsection{The Role of Genetic Polymorphism in the Trace Elements}

A genome-wide association (GWA) study identified a single nucleotide polymorphism (SNP) in rs738409 in the patatin-like phospholipase domain containing 3 (PNPLA3) gene, which is recognized as an adiponutrin gene, and the SNP was strongly associated with the grade of hepatic fat content [148]. The PNPLA3 risk allele homozygosity was associated with an increased risk for NASH [149]. Moreover, rs738409 also showed a strong association with hepatic iron deposition in Japanese NAFLD patients [150].

The PNPLA3 G allele also affects the development of hepatic steatosis in Wilson's disease. However, the PNPLA3 G allele was not associated with the hepatic $\mathrm{Cu}$ content in such patients [151].

The IL-6-174 G/C promotor polymorphism affected the hepatic Zn content in autopsy cases [152]. Since Zn supplementation ( $9.08 \mathrm{mg} / 100 \mathrm{~g}$ weight of zinc sulfate) ameliorates the synthesis of IL-6 in salmonella-induced hepatic damage in a murine model [153], an IL-6 SNP may be involved in the pathogenesis of $\mathrm{Zn}$ deficiency in patients with CLDs.

\subsection{The Roles of Microbiota in Trace Elements}

Sequencing the 16S gene ribosomal RNA (rRNA) has become a popular method for identifying bacterial communities [154]. Next-generation sequencing enabled us to investigate the relationship between the composition of microbiomes and dysbiosis [155].

Gut dysbiosis frequently causes a variety of critical complications, including endotoxemia and hepatic encephalopathy, in patients with liver cirrhosis. These severe complications are likely to be derived from small intestinal bacterial overgrowth and/or an increase in intestinal permeability, termed "leaky gut" [156]. Notably, bacterial translocation is ordinarily observed in the portal vein as well as hepatic and peripheral blood of patients with decompensated liver cirrhosis [157]. Bacterial translocation of gut flora was dominated primarily by the Proteobacteria phylum in such patients [158]. These species are commonly present in both the peripheral and portal blood of patients with liver cirrhosis, and were considered to be strong producers of iron chelates (siderophores). Indeed, both the peripheral blood and portal blood of cirrhotic patients were enriched in bacterial Kegg Orthologous genes linked to active Fe transport [159]. These results may suggest that Proteobacteria phylum is functionally linked to Fe metabolism.

It is well recognized that the microbiota also plays a crucial role in the pathogenesis of NAFLD [160]. Song et al. documented that (1) a dietary $\mathrm{Cu}$-fructose interaction regulated gut microbiota and that (2) the alteration of gut flora via the gut barrier dysfunction might result in the development of steatosis in the liver. The gut barrier dysfunction was derived from markedly downregulated intestinal tight junction proteins and increased gut permeability [161]. Indeed, the alterations of microbiome indicated an increase in Firmicutes and a depletion of Akkermansia, which is considered to be crucial for maintaining the gut burrier function. 


\subsection{The Roles of Sarcopenia in Trace Elements}

Sarcopenia, characterized by a loss of skeletal muscle mass and low muscle strength [162], is one of the common features in patients with CLD, which is observed even in NAFLD patients [163] as well as cirrhosis patients [164]. It is well documented that several types of minerals, including $\mathrm{Mg}$, calcium (Ca), and Se, play pivotal roles in muscle metabolism [7,165]. It remains controversial whether an excessive Fe status contributes to sarcopenia $[166,167]$. Nishikawa et al. contended that Zn deficiency might account for sarcopenia in patients with CLD [168], although a putative mechanism by which Zn deficiency causes sarcopenia in such patients remains unclear. The combination treatment of $\mathrm{Zn}$ with a branched chain amino acid may be effective in liver cirrhosis patients with sarcopenia [169].

Several studies revealed that in elderly people, lower serum Se levels are associated with a lower muscle mass [170]. It is plausible that treatment with fish oil and Se attenuated skeletal muscle atrophy by preventing a rise in myostatin [171], which is a negative regulator of muscle mass [172].

\subsection{The Role of MicroRNA in Trace Elements}

MicroRNAs (miRNAs), which are small, single stranded non-coding RNAs of 19-25 nucleotide in length, negatively regulate gene expression via translational inhibition or messenger RNA (mRNA) degradation [173]. Many miRNAs play essential roles in diverse biological processes, including cell differentiation, proliferation, migration, and survival [174].

Some kinds of miRNAs are also involved in the pathogenesis of NAFLD [175]. Especially, increases in the expressions of miR-200a and miR-223 were negatively correlated with iron regulatory protein 1 (IRP1) in a mouse model of NAFLD, implying that miRNAs might contribute to Fe homeostasis in patients with NAFLD [176].

\section{Conclusions}

Much novel evidence has accumulated regarding the roles of essential trace elements in CLDs by recent advances in various types of molecular biological technologies. Some of the trace elements were extremely useful for the prediction of the prognosis in patients with CLDs. The beneficial therapeutic effects of some trace elements supplementations have been confirmed in experimental animal models and/or clinical trials. However, the evidence levels remain relatively low. Further prospective multicenter cohort studies should be conducted to investigate the usefulness of the essential trace elements in CLDs.

Author Contributions: T.H. wrote the manuscript. T.M. made critical revisions. All authors have read and agreed to the published version of the manuscript.

Funding: This research received no external funding.

Conflicts of Interest: The authors have no conflicts of interest to declare.

\section{Abbreviations}

$\begin{array}{ll}\text { AIH } & \text { autoimmune hepatitis } \\ \text { ALT } & \text { alanine aminotransferase } \\ \text { CLD } & \text { chronic liver disease } \\ \mathrm{Cu} & \text { copper } \\ \mathrm{Fe} & \text { iron } \\ \text { GPx } & \text { glutathione peroxidase } \\ \text { HCC } & \text { hepatocellular carcinoma } \\ \text { HBV } & \text { hepatitis B virus } \\ \text { HCV } & \text { hepatitis C virus } \\ \text { HEV } & \text { hepatitis E virus } \\ \text { HOMA-IR } & \text { homeostasis model for assessment of insulin resistance }\end{array}$ 


$\begin{array}{ll}\text { HSC } & \text { hepatic stellate cell } \\ \text { HSC } & \text { hepatic stellate cell } \\ \text { IFN } & \text { interferon } \\ \text { IL-6 } & \text { interleukin-6 } \\ \text { Mg } & \text { magnesium } \\ \text { miRNA } & \text { microRNA } \\ \text { MT } & \text { metallothionein } \\ \text { NAFLD } & \text { nonalcoholic fatty liver disease } \\ \text { NASH } & \text { nonalcoholic steatohepatitis } \\ \text { PBC } & \text { primary biliary cholangitis } \\ \text { ROS } & \text { reactive oxygen species } \\ \text { Se } & \text { selenium } \\ \text { SNP } & \text { single nucleotide polymorphism } \\ \text { Zn } & \text { zinc }\end{array}$

\section{References}

1. Ritland, S.; Aaseth, J. Trace elements and the liver. J. Hepatol. 1987, 5, 118-122. [CrossRef]

2. McClain, C.J.; Marsano, L.; Burk, R.F.; Bacon, B. Trace metals in liver disease. Semin. Liver Dis. 1991, 11, 321-339. [CrossRef] [PubMed]

3. Nordberg, M.; Nordberg, G.F. Trace element research-historical and future aspects. J. Trace Elem. Med. Biol. 2016, 38, 46-52. [CrossRef] [PubMed]

4. Gilca-Blannariu, G.E.; Diaconescu, S.; Ciocoiu, M.; Stefanescu, G. New insights into the role of trace elements in IBD. Biomed. Res. Int. 2018, 1813047. [CrossRef] [PubMed]

5. Kaur, B.; Henry, J. Micronutrient status in type 2 diabetes: A review. Adv. Food Nutr. Res. 2014, 71, 55-100.

6. Wolide, A.D.; Zawdie, B.; Alemayehu, T.; Tadesse, S. Association of metal elements with lipid profiles in type 2 diabetes mellitus patients: A cross sectional study. BMC Endocr. Disord. 2017, 17, 64. [CrossRef] [PubMed]

7. Verlaan, S.; Aspray, T.J.; Bauer, J.M.; Cederholm, T.; Hemsworth, J.; Hill, T.R.; McPhee, J.S.; Piasecki, M.; Seal, C.; Sieber, C.C.; et al. Nutritional status, body composition, and quality of life in community-dwelling sarcopenia and non-sarcopenic older adults: A case-control study. Clin. Nutr. 2017, 36, 267-274. [CrossRef]

8. Gupta, S.; Read, S.; Shackel, N.A.; Hebbard, L.; George, J.; Ahlenstiel, G. The role of micronutrients in the infection and subsequent response to hepatitis C virus. Cells 2019, 8, 603. [CrossRef]

9. Guillin, O.M.; Vindry, C.; Ohlmann, T.; Chavatte, L. Selenium, selenoprotein and viral infection. Nutrients 2019, 11, 2101. [CrossRef] [PubMed]

10. Ozgenc, F.; Aksu, G.; Kirkpinar, F.; Altuglu, I.; Coker, I.; Kutukculer, N.; Yagci, R.V. The influence of marginal zinc deficient diet on post-vaccination immune response against hepatitis B in rats. Hepatol. Res. 2006, 35, 26-30. [CrossRef]

11. Zhao, N.; Wang, X.; Zhang, Y.; Gu, Q.; Huang, F.; Zheng, W.; Li, Z. Gestational zinc deficiency impairs humoral and cellular immune responses to hepatitis B vaccination in offspring mice. PLOS ONE 2013, 8, e73461. [CrossRef] [PubMed]

12. Yuasa, K.; Naganuma, A.; Sato, K.; Ikeda, M.; Kato, N.; Takagi, H.; Mori, M. Zinc is a negative regulator of hepatitis C virus RNA replication. Liver Int. 2006, 26, 1111-1118. [CrossRef] [PubMed]

13. Read, S.A.; Parnell, G.; Booth, D.; Douglas, M.W.; George, J.; Ahlenstiel, G. The antiviral role of zinc and metalloproteins in hepatitis C infection. J. Viral Hepat. 2018, 25, 491-501. [CrossRef] [PubMed]

14. Read, S.A.; O'Connor, K.S.; Suppiah, V.; Ahlenstiel, C.L.E.; Obeid, S.; Cook, K.M.; Cunningham, A.; Douglas, M.W.; Hogg, P.J.; Booth, D.; et al. Zinc is a potent and specific inhibitor of IFN- $\lambda 3$ signaling. Nat. Commun. 2017, 8, 15245. [CrossRef]

15. Zhang, W.; Ramanathan, C.S.; Nadimpali, R.G.; Bhat, A.A.; Cox, A.G.; Taylor, E.W. Selenium-dependent glutathione peroxidase modules encoded by RNA viruses. Biol. Trace Elem. Res. 1999, 70, 97-116. [CrossRef]

16. Murai, K.; Honda, M.; Shirasaki, T.; Shimakami, T.; Omura, H.; Mizu, H.; Kita, Y.; Takeshita, Y.; Ishii, K.; Takamura, T.; et al. Induction of selenoprotein P mRNA during hepatitis $\mathrm{C}$ virus infection inhibits RIG-I-mediated antiviral immunity. Cell Host Microbe 2019, 10, 588-601. [CrossRef] 
17. Kakizaki, S.; Takagi, H.; Horiguchi, N.; Toyoda, M.; Takayama, H.; Nagamine, T.; Mori, M.; Kato, N. Iron enhances hepatitis C virus replication in cultured human hepatocytes. Liver 2000, 20, 125-128. [CrossRef] [PubMed]

18. Fillebeelos, K. Iron inhibits replication of infectious hepatitis $C$ virus in permissive Huh 7.5.1 cells. J. Hepatol. 2010, 53, 995-999. [CrossRef] [PubMed]

19. Wang, Q.; Liu, Y.; An, D.; Diao, H.; Xu, W.; He, X.; Sun, R.; Wei, L.; Li, L. Regulation of hepatitis C virus translation inhibition by iron: Role of elF3 and La protein. Virus Res. 2012, 167, 302-309. [CrossRef] [PubMed]

20. Foka, P.; Dimitriadis, A.; Karamichali, E.; Kyratzopoulou, E.; Giannimaras, D.; Koskinas, J.; Varaklioti, A.; Mamalaki, A.; Georgopoulou, U. Alteration in the iron homeostasis network: A driving force for macrophage-mediated hepatitis $C$ virus persistency. Virulence 2016, 7, 679-690. [CrossRef] [PubMed]

21. Hang, X.; Peng, H.; Song, H.; Qi, Z.; Miao, X.; Xu, W. Antiviral activity cuprous oxide nanoparticles against hepatitis C virus in vitro. J. Virol. Methods 2015, 222, 150-157. [CrossRef] [PubMed]

22. Kaushik, N.; Subramani, C.; Anang, S.; Muthumohan, R.; Shalimar; Nayak, B.; Ranjith-Kumar, C.T.; Surjit, M. Zinc salts block hepatitis $\mathrm{E}$ virus replication by inhibiting the activity of viral RNA-dependent RNA polymerase. J. Virol. 2017, 91, e00754-17. [CrossRef] [PubMed]

23. Liaw, Y.F.; Chu, C.M. Hepatitis B virus infection. Lancet 2009, 373, 582-592. [CrossRef]

24. Maares, M.; Haase, H. Zinc and immunity: An essential interrelation. Arch. Biochem. Biophys. 2016, 611, 58-65. [CrossRef] [PubMed]

25. Cheng, Z.; Zhi, X.; Sun, G.; Guo, W.; Huang, Y.; Sun, W.; Tian, X.; Zhao, F.; Hu, K. Sodium selenite suppresses hepatitis B virus transcription and replication in human hepatoma cell lines. J. Med. Virol. 2016, 88, 653-663. [CrossRef]

26. Thrift, A.P.; El-Serag, H.B.; Kanwal, F. Global epidemiology and burden of HCV infection and HCV-related disease. Nat. Rev. Gastroenterol. Hepatol. 2017, 14, 122-132. [CrossRef]

27. Negro, F. Mechanisms of hepatitis C virus-related insulin resistance. Clin. Res. Hepatol. Gastroenterol. 2011, 35, 358-363. [CrossRef]

28. Tedbury, P.R.; Harris, M. Characterization of the roles of zinc in hepatitis C virus NS2/3 auto-cleavage and NS3 protease activities. J. Mol. Biol. 2007, 366, 1652-1660. [CrossRef]

29. Stempniak, M.; Hostomska, Z.; Nodes, B.R.; Hostomsky, Z. The NS3 proteinase domain of hepatitis C virus is a zinc-containing enzyme. J. Virol. 1997, 71, 2881-2887. [CrossRef]

30. Tellinghuisen, T.L.; Marcotrigiano, J.; Gorbalenya, A.E.; Rice, C.M. The NS5A protein of hepatitis C virus is a zinc metallporotein. J. Biol. Chem. 2004, 279, 48576-48587. [CrossRef]

31. Read, S.A.; Obeid, S.; Ahlenstiel, C.; Ahlenstiel, G. The role of antiviral immunity. Adv. Nutr. 2019, 10, 696-710. [CrossRef] [PubMed]

32. Suda, T.; Okawa, O.; Shirahashi, R.; Tokutomi, N.; Tamano, M. Changes in serum zinc levels in hepatitis C patients before and after treatment with direct-acting antiviral agents. Hepatol. Res. 2019, 49, 1353-1356. [CrossRef] [PubMed]

33. Ko, W.S.; Guo, C.H.; Yeh, M.S.; Lin, L.Y.; Hsu, G.S.W.; Chen, P.C.; Luo, M.C.; Lin, C.Y. Blood micronutrient, oxidative stress, and viral load in patients with chronic hepatitis C. World J. Gastroenterol. 2005, 11, 4697-4702. [CrossRef] [PubMed]

34. Himoto, T.; Yoneyama, H.; Kurokohchi, K.; Inukai, M.; Masugata, H.; Goda, F.; Haba, R.; Watanabe, S.; Kubota, S.; Senda, S.; et al. Selenium deficiency is associated with insulin resistance in patients with hepatitis C virus-related chronic liver disease. Nutr. Res. 2011, 31, 829-835. [CrossRef] [PubMed]

35. Duncan, A.; Talwar, D.; McMillan, D.C.; Stefanowicz, F.; O’Reilly, D.S. Quantitative data on magnitude of the systemic inflammatory response and effect on micronutrient status based on plasma measurements. Am. J. Clin. Nutr. 2012, 95, 64-71. [CrossRef] [PubMed]

36. Liu, H.; Trinh, T.L.; Dong, H.; Keith, R.; Nelson, D.; Liu, C. Iron regulator hepcidin exhibits antiviral activity against hepatitis C virus. PLoS ONE 2012, 7, e46631. [CrossRef] [PubMed]

37. Ross, M.J.; Bradford, S.S.; Cowan, J.A. Catalytic metallodrugs based on the LaR2C peptide target HCV SLIV IRES RNA. Dalton Trans. 2015, 44, 20972-20982. [CrossRef]

38. Kamar, N.; Lhomme, S.; Abravanel, F.; Marion, O.; Peron, J.M.; Alric, L.; Izopet, J. Treatment of HEV infection in patients with solid-organ transplant and chronic hepatitis. Viruses 2016, 8, 222. [CrossRef] 
39. Proudfoot, A.; Hyrina, A.; Holdorf, M.; Frank, A.O.; Bussiere, D. First crystal structure of a nonstructural hepatitis E viral protein identifies a putative novel zinc-binding protein. J. Virol. 2019, 93, e00170-19. [CrossRef]

40. Stamoulis, I.; Kouraklis, G.; Theocharis, S. Zinc and liver: An active interaction. Dig. Dis. Sci. 2007, 52, 1595-1612. [CrossRef]

41. Mohammad, M.K.; Zhou, Z.; Cave, M.; Barve, A.; McClain, C.J. Zinc and Liver disease. Nutr. Clin. Pract. 2012, 27, 8-20. [CrossRef] [PubMed]

42. Himoto, T.; Masaki, T. Association between zinc deficiency and metabolic abnormalities in patients with chronic liver disease. Nutrients 2018, 10, 88. [CrossRef] [PubMed]

43. Loguercio, C.; De Girolamo, V.; Federico, A.; Feng, S.L.; Cataldi, V.; Del Vecchio Blanco, C.; Gialanella, G. Trace elements and chronic liver diseases. J. Trace Elem. Med. Biol. 1997, 11, 158-161. [CrossRef]

44. Kalkan, A.; Bulut, V.; Avci, S.; Celik, I.; Bingol, N.K. Trace elements in viral hepatitis. J. Trace Elem. Med. Biol. 2002, 16, 227-230. [CrossRef]

45. Özbal, E.; Helvaci, M. Serum zinc as a factor predicting response to interferon- $\alpha 2 b$ therapy in children with chronic hepatitis B. Biol. Trace Elem. Res. 2002, 91, 31-38. [CrossRef]

46. Hatano, R.; Ebara, M.; Fukuda, H.; Yoshikawa, M.; Sugiura, N.; Kondo, F.; Yukawa, M.; Saisho, H. Accumulation of copper in the liver and hepatic injury in chronic hepatitis C. J. Gastroenterol. Hepatol. 2000, 15, 786-791. [CrossRef]

47. Moriyama, M.; Matsumura, H.; Fukushima, A.; Ohkido, K.; Arakawa, Y.; Nirei, K.; Yamagami, H.; Kaneko, M.; Tanaka, N.; Arakawa, Y. Clinical significance of evaluation of serum zinc concentrations in C-viral chronic liver disease. Dig. Dis. Sci. 2006, 51, 1967-1977. [CrossRef]

48. Himoto, T.; Yoneyama, H.; Deguchi, A.; Kurokohchi, K.; Inukai, M.; Masugata, H.; Goda, F.; Senda, S.; Watanabe, S.; Kubota, S.; et al. Insulin resistance derived from zinc deficiency in non-diabetic patients with chronic hepatitis C. Exp. Med. 2010, 1,707-711. [CrossRef]

49. Reda, R.; Abbas, A.A.; Mohammed, M.; El Fedawy, S.F.; Ghareeb, H.; El Kabarity, R.H.; Abo-Shady, R.A.; Zakaria, D. The interplay between zinc, vitamin D, and IL-17 in patients with chronic hepatitis C liver disease. J. Immunol. Res. 2015, 2015, 846348. [CrossRef]

50. Guo, C.H.; Chen, P.C.; Ko, W.S. Status of essential trace minerals and oxidative stress in viral hepatitis C patients with nonalcoholic fatty liver disease. Int. J. Med. Sci. 2013, 10, 730-737. [CrossRef]

51. Kosari, F.; Jamali, R.; Ramin, T.; Mozavi Jahan Abad, E. The correlation between serum zinc level and liver histology in non-alcoholic steatohepatitis. Iran. J. Pathol. 2019, 14, 17-25. [CrossRef] [PubMed]

52. Asprouli, E.; Kalafati, I.P.; Sakellari, A.; Karavoltsos, S.; Vlachogiannakos, J.; Revenas, K.; Kokkinos, A.; Dassenakis, M.; Dedoussis, G.V.; Kalogeropoulos, N. Evaluation of plasma trace elements in different stage of nonalcoholic fatty liver disease. Biol. Trace Elem. Res. 2019, 188, 326-333. [CrossRef] [PubMed]

53. Ito, T.; Ishigami, M.; Ishizu, Y.; Kuzuya, T.; Honda, T.; Ishikawa, T.; Toyoda, H.; Kumada, T.; Fujishiro, M. Correlation of serum zinc levels with pathological and laboratory findings in patients with nonalcoholic fatty liver disease. Eur. J. Gastroenteol. Hepatol. 2020, 32, 748-753. [CrossRef] [PubMed]

54. Khan, M.S.; Dilawar, S.; Ali, I.; Rauf, N. The possible role of selenium concentration in hepatitis B and C patients. Saudi J. Gastroenterol. 2012, 18, 106-110. [CrossRef] [PubMed]

55. Levent, G.; Ali, A.; Ahmet, A.; Polat, E.C.; Ayatac, C.; Ayse, E.; Ahmet, S. Oxidative stress and antioxidant defense in patients with chronic hepatitis $C$ patients before and after pegylated interferon alfa- $2 b$ plus ribavirin therapy. J. Transl. Med. 2006, 4, 25. [CrossRef] [PubMed]

56. Yang, Z.; Yan, C.; Liu, G.; Niu, Y.; Zhang, W.; Lu, S.; Li, X.; Zhang, H.; Ning, G.; Fan, J.; et al. Plasma selenium levels and nonalcoholic fatty liver disease in Chinese adults: A cross-sectional analysis. Sci. Rep. 2016, 6, 37288. [CrossRef]

57. Swiderska, M.; Maciejczyk, M.; Zalewska, A.; Pogorzelska, J.; Flisiak, R.; Chabowski, A. Oxidative stress biomerkers in the serum and plasma of patients with non-alcoholic fatty liver disease (NAFLD). Can plasma AGE be a marker of NAFLD? Oxidative stress biomarkers in NAFLD patients. Free Radic. Res. 2019, 53, 841-850. [CrossRef]

58. Kohgo, Y.; Ikuta, K.; Ohtake, T.; Torimoto, Y.; Kato, J. Iron overload and cofactors with special reference to alcohol, hepatitis C virus infection and steatosis/insulin resistance. World J. Gastroenterol. 2007, 13, 4699-4706. [CrossRef] 
59. Himoto, T.; Nomura, T.; Tani, J.; Miyoshi, H.; Morishita, A.; Yoneyama, H.; Haba, R.; Masugata, H.; Masak, T. Exacerbation of insulin resistance and hepatic steatosis deriving from zinc deficiency in patients with HCV-related chronic liver disease. Biol. Trace Elem. Res. 2015, 163, 81-88. [CrossRef] [PubMed]

60. Ratziu, V.; Belllentani, S.; Cortez-Pinto, H.; Day, C.; Marchesini, G. A position statement on NAFLD/NASH based on the EASL 2009 special conference. J. Hepatol. 2010, 53, 372-384. [CrossRef]

61. Kowdley, K.V.; Belt, P.; Wilson, L.A.; Yeh, M.M.; Neuschwander-Tetri, B.A.; Chalasani, N.; Sanyal, A.J.; Nelson, J.E.; NASH Clinical Research Network. Serum ferritin is an independent predictor of histologic severity and advanced fibrosis in patients with nonalcoholic fatty liver disease. Hepatology 2012, 55, 77-85. [CrossRef] [PubMed]

62. Miura, K.; Taura, K.; Kodama, Y.; Schnabl, B.; Brenner, D.A. Hepatitis C virus-induced oxidative stress suppresses hepcidin expression through increased histone deacetylase activity. Hepatology 2008, 48, 1420-1429. [CrossRef] [PubMed]

63. Aigner, E.; Weiss, G.; Datz, C. Dysregulation of iron and copper homeostasis in nonalcoholic fatty liver. World J. Hepatol. 2015, 7, 177-188. [CrossRef] [PubMed]

64. Himoto, T.; Fujita, K.; Nomura, T.; Tani, J.; Miyoshi, H.; Morishita, A.; Yoneyama, H.; Kubota, S.; Haba, R.; Suzuki, Y.; et al. Roles of copper in hepatocarcinogenesis via the activation of hypoxia-inducible factor- $1 \alpha$. Biol. Trace Elem. Res. 2016, 174, 58-64. [CrossRef] [PubMed]

65. Aigner, E.; Strasser, M.; Haufe, H.; Sonnweber, T.; Hohla, F.; Stadlmayr, A.; Solioz, M.; Tilg, H.; Patsch, W.; Weiss, G.; et al. A role for hepatic copper concentrations in nonalcoholic fatty liver disease. Am. J. Gastroenterol. 2010, 105, 1978-1985. [CrossRef] [PubMed]

66. Nobili, V.; Siotto, M.; Bedogni, G.; Rava, L.; Pietrobattista, A.; Panera, N.; Alisi, A.; Squitti, R. Levels of serum ceruloplasmin associate with pediatoric nonalcoholic fatty liver disease. J. Pediatr. Gastroenterol. Nutr. 2013, 56, 370-375. [CrossRef] [PubMed]

67. Himoto, T.; Hosomi, N.; Nakai, S.; Deguchi, A.; Kinekawa, F.; Matsuki, M.; Yachida, M.; Masaki, T.; Kurokochi, K.; Watanabe, S.; et al. Efficacy of zinc administration in patients with hepatitis C virus-associated chronic liver disease. Scand. J. Gastroenterol. 2007, 42, 1078-1087. [CrossRef]

68. Matsumura, H.; Nirei, K.; Nakamura, H.; Arakawa, Y.; Higuchi, T.; Hayashi, J.; Yamagami, H.; Matsuoka, S.; Ogawa, M.; Nakajima, N.; et al. Zinc supplementation therapy improves the outcome of patients with chronic hepatitis C. J. Clin. Biochem. Nutr. 2012, 51, 178-184. [CrossRef]

69. Takagi, H.; Nagamine, T.; Abe, T.; Takayama, H.; Sato, K.; Otsuka, T.; Kakizaki, S.; Hashimoto, Y.; Matsumoto, T.; Kojima, A.; et al. Zinc supplementation enhances the response to interferon therapy in patients with chronic hepatitis C. J. Viral Hepat. 2001, 8, 367-371. [CrossRef]

70. Murakami, Y.; Koyabu, T.; Kawashima, A.; Kakibuchi, N.; Kawakami, T.; Takaguchi, K.; Kita, K.; Okita, M. Zinc supplementation prevents the increase of transaminase in chronic hepatitis $\mathrm{C}$ patients during combination therapy with pegylated interferon $\alpha-2 b$ and ribavirin. J. Nutr. Sci. Vitam. 2007, 53, 213-218. [CrossRef]

71. Suzuki, H.; Takagi, H.; Sohara, N.; Kanda, N.; Kakizaki, S.; Sato, K.; Mori, M. Gunma Liver Study Group. Triple therapy of interferon and ribavirin with zinc supplementation for patients with chronic hepatitis C: A randomized controlled clinical trial. World J. Gastroenterol. 2006, 28, 1265-1269. [CrossRef] [PubMed]

72. Look, M.P.; Gerard, A.; Rao, G.S.; Sudhop, T.; Fischer, H.P.; Sauerbruch, T.; Spengler, U. Interferon/antioxidant combination therapy for chronic hepatitis C-a controlled pilot trial. Antivir. Res. 1999, 43, 113-122. [CrossRef]

73. Diglio, D.C.; Fernandes, S.A.; Stein, J.; Azeredo-da-Silva, A.; De Mattos, A.A.; Tovo, C.V. Role of zinc supplementation in management of chronic liver diseases: A sysmematic review and meta-analysis. Ann. Hepatol. 2020, 19, 19-196. [CrossRef] [PubMed]

74. Takahashi, M.; Saito, H.; Higashimoto, T.; Hibi, T. Possible inhibitory effect of zinc supplementation on hepatic fibrosis through downregulation of TIMP-1: A pilot study. Hepatol. Res. 2007, 37, 405-409. [CrossRef] [PubMed]

75. Somi, M.H.; Rezaeifar, P.; Ostad Rahimi, A.; Moshrefi, B. Effects of low dose zinc supplementation on biochemical markers in non-alcoholic cirrhoisis. Arch. Iran. Med. 2012, 15, 472-476. [PubMed]

76. Burk, R.F.; Hill, K.E.; Motley, A.K.; Byrne, D.W.; Norsworthy, B.K. Selenium deficiency occurs in some patients with moderate-to-severe cirrhosis and can be corrected by administration of selenite but not selenomethionine: A randomized control trial. Am. J. Clin. Nutr. 2015, 102, 1126-1133. [CrossRef] [PubMed] 
77. Välimäki, M.; Alfthan, G.; Vuristo, M.; Ylikahri, R. Effects of selenium supplementation on blood and urine selenium levels and liver function in patients with primary biliary cirrhosis. Clin. Chim. Acta 1991, 196, 7-16. [CrossRef]

78. Groenbaek, K.; Friis, H.; Hansen, M.; Ring-Larsen, H.; Krarup, H.B. The effect of antioxidant supplementation on hepatitis $\mathrm{C}$ viral load, transaminazes and oxidative status: A randomized trial among chronic hepatitis $\mathrm{C}$ virus-infected patients. Eur. J. Gastroenterol. Hepatol. 2006, 18, 985-989. [CrossRef]

79. Hayashi, H.; Takikawa, T.; Nishimaru, N.; Yano, M.; Isomura, T.; Sakamoto, N. Improvement of serum aminotransferase levels after phlebotomy in patients with chronic active hepatitis $\mathrm{C}$ and excess hepatic iron. Am. J. Gastroenterol. 1994, 89, 986-988. [PubMed]

80. Kato, J.; Kobune, M.; Nakamura, T.; Kuroiwa, G.; Takada, K.; Takimoto, R.; Sato, Y.; Fujikawa, K.; Takahashi, M.; Takayama, T.; et al. Normalization of elevated hepatic 8-hydroxy-2'-deoxyguanosine levels in chronic hepatitis C patients by phlebotomy and low iron diet. Cancer Res. 2001, 61, 8697-8702. [PubMed]

81. Valenti, L.; Fracanzani, A.L.; Dongiovannni, P.; Rovida, S.; Rametta, R.; Fatta, E.; Pulixi, E.A.; Maggioni, M.; Fargion, S. A randomized trial of iron depletion in patients with nonalcoholic fatty liver disease and hyperferritinemia. World J. Gastroenterol. 2014, 20, 3002-3010. [CrossRef] [PubMed]

82. Khodadoostan, M.; Zamanidoost, M.; Shavakhi, A.; Sanei, H.; Shahbazi, M.; Ahmadian, M. Effects of phlebotomy on liver enzymes and histology of patients with nonalcoholic fatty liver disease. Adv. Biomed. Res. 2017, 6, 12. [PubMed]

83. Burk, R.F.; Hill, K.E. Regulation of selenium metabolism and transport. Ann. Rev. Nutr. 2015, 35, $109-134$. [CrossRef] [PubMed]

84. Bettinger, D.; Schulthesis, M.; Hennecke, N.; Panther, E.; Knüppel, E.; Blum, H.E.; Thimme, R.; Spangenberg, H.C. Selenium levels in patients with hepatitis C-related chronic hepatitis, liver cirrhosis, and hepatocellular carcinoma: A pilot study. Hepatology 2013, 57, 2543-2544. [CrossRef] [PubMed]

85. Khedr, M.H.; El-Araby, H.A.; Konsowa, H.A.; Sokar, S.S.; Mahmoud, M.F.; Adawy, N.M.; Zakaria, H.M. Glutathione peroxidase and malondialdehyde in children with chronic hepatitis C. Clin. Exp. Hepatol. 2019, 5, 81-87. [CrossRef] [PubMed]

86. Liu, L.; Geng, X.; Cai, Y.; Copple, B.; Yoshinaga, M.; Shen, J.; Nebert, D.W.; Wang, H.; Liu, Z. Hepatic ZIP8 deficiency is associated with disrupted selenium homeostasis, liver pathology, and tumor formation. Am. J. Physiol. Gastrointest. Liver Physiol. 2018, 315, G569-G579. [CrossRef] [PubMed]

87. Chen, L.; Pan, D.D.; Zhou, J.; Jiang, Y.Z. Protective effect of selenium-enriched lactobacillus on $\mathrm{CCl}_{4}$-induced liver injury in mice and its possible mechanisms. World J. Gastroenterol. 2005, 11, 5795-5800. [CrossRef] [PubMed]

88. Fatmi, W.; Kechrid, Z.; Naziroglu, M.; Flores-Arce, M. Selenium supplementation modulates zinc levels and antioxidant values in blood and tissues of diabetic rats fed zinc-deficient diet. Biol. Trace Elem. Res. 2013, 152, 243-250. [CrossRef]

89. Fernandez-Real, J.M.; Manco, M. Effects of iron overload on chronic metabolic diseases. Lancet Diabetes Endcrinol. 2014, 2, 513-526. [CrossRef]

90. Nemeth, E.; Tuttle, M.; Powelson, J.; Vaughn, M.B.; Donovan, A.; Ward, D.M.; Ganz, T.; Kaplan, J. Hepcidin regulates cellular iron efflux by binding to ferroportin and inducing its inteenalization. Science 2004, 306, 2090-2093. [CrossRef]

91. Barber, E.F.; Cousins, R.J. Interleukin-1-stimulated induction of ceruloplasmin synthesis in normal and copper-deficient rats. J. Nutr. 1988, 118, 375-381. [CrossRef] [PubMed]

92. European Association for Study of Liver. EAS Clinical practice guidelines: Wilson's disease. J. Hepatol. 2012, 56, 671-685. [CrossRef] [PubMed]

93. Sakurai, H.; Satoh, H.; Hatanaka, A.; Sawada, T.; Kawano, K.; Hagino, T.; Nakajima, K. Unusual generation of hydroxyl radicals in hepatic copper-metallothionein of LEC (Long Evans Cinnamon) rats in the presence of hydrogen peroxide. Biochem. Biophys. Res. Commun. 1994, 199, 313-318. [CrossRef] [PubMed]

94. Hassan, I.; Ebaid, H.; Alhazza, I.M.; Al-Tamimi, J.; Aman, S.; Abdel-Magneed, A.M. Copper mediates anti-inflammatory and antifibrotic activity of Gleevec in hepatocellular carcinoma-induced male rats. Can. J. Gastroenterol. Hepatol. 2019, 9897315. [CrossRef] [PubMed]

95. Iimuro, Y.; Nishio, T.; Morimoto, T.; Nitta, T.; Stefanovic, B.; Choi, S.K.; Brenner, D.A.; Yamaoka, Y. Delivery of matrix metalloproteinase-1 attenuates established liver fibrosis in the rat. Gastroenterology 2003, 124, 445-458. [CrossRef] 
96. Anttinen, H.; Ryhänen, L.; Puistola, U.; Arranto, A.; Oikarinen, A. Decrease in liver collagen accumulation in carbon tetrachloride-injuryed and normal growing upon administration of zinc. Gastroenterolgy 1984, 86, 532-539. [CrossRef]

97. Kojima-Yuasa, A.; Ohkita, T.; Yukami, K.; Ichikawa, H.; Takami, N.; Nakatani, T.; Kennedy, D.O.; Matsui-Yuasa, I. Involvement of intracellular glutathione in zinc deficiency-induced activation of hepatic stellate cells. Chem. Biol. Interact. 2003, 146, 89-99. [CrossRef]

98. Ye, J.; Zhang, Z.; Zhu, L.; Lu, M.; Li, Y.; Zhou, J.; Lu, X.; Du, Q. Polaprezinc inhibits liver fibrosis and proliferation in hepatocellular carcinoma. Mol. Med. Rep. 2017, 16, 5523-5528. [CrossRef] [PubMed]

99. Sugino, H.; Kumagai, N.; Watanabe, S.; Toda, K.; Takeuchi, O.; Tsunematsu, S.; Morinaga, S.; Tsuchimoto, K. Polaprezinc attenuates liver fibrosis in a mouse model of non-alcoholic steatohepatitis. J. Gastroenterol. Hepatol. 2008, 23, 1909-1916. [CrossRef] [PubMed]

100. Kono, T.; Asama, T.; Chisato, N.; Ebisawa, Y.; Okayama, T.; Imai, K.; Karasaki, H.; Furukawa, H.; Yoneda, M. Polaprezinc ongoing thioacetamide-induced liver fibrosis in rats. Life Sci. 2012, 90, 122-130. [CrossRef] [PubMed]

101. Bashandy, S.A.E.; Alaamer, A.; Moussa, S.A.A.; Omara, E.A. Role of zinc oxide nanoparticles in alleviating hepatic fibrosis and nephrotoxicity induced by thioacetamide in rats. Can. J. Physiol. Parmacol. 2018, 96, 337-344. [CrossRef] [PubMed]

102. Duncan, A.; Yacoubian, C.; Watson, N.; Morrison, I. The risk copper deficiency in patients prescribed zinc supplementation. J. Clin. Pathol. 2015, 68, 723-725. [CrossRef] [PubMed]

103. Burk, R.F.; Early, D.S.; Hill, K.E.; Palmer, I.S.; Boeglin, M.E. Plasma selenium in patients with cirrhosis. Hepatology 1998, 27, 794-798. [CrossRef] [PubMed]

104. Thuluvath, P.J.; Triger, D.R. Selenium in chronic liver disease. J. Hepatol. 1992, 14, 176-182. [CrossRef]

105. Jorge, J. Determination of selenium during pathogenesis of hepatic fibrosis employing hydride generation and inductively coupled plasma mass spectrometry. Biol. Chem. 2018, 399, 499-509.

106. Ding, M.; Potter, J.J.; Liu, X.; Torbenson, M.S.; Mezey, E. Selenium supplementation decreases hepatic fibrosis in mice after chronic carbon tetrachloride administration. Biol. Trace Elem. Res. 2010, 133, 83-97. [CrossRef]

107. Mehta, K.J.; Je Farnaud, S.; Sharp, P.A. Iron and liver fibrosis: Mechanism and clinical aspects. World J. Gastroenterol. 2019, 25, 521-538. [CrossRef]

108. Hezode, C.; Cazeneuve, C.; Coue, O.; Roudot-Thoraval, F.; Lonjon, I.; Bastie, A.; Duvoux, C.; Pawlotsky, J.M.; Zafrani, E.S.; Amselem, S.; et al. Liver iron accumulation in patients with chronic active hepatitis C: Prevalence and role of hemochromatosis gene mutations and relationship with hepatic histological lesions. J. Hepatol. 1999, 31, 979-984. [CrossRef]

109. Saito, H.; Fujimoto, Y.; Ohtake, T.; Suzuki, Y.; Sakurai, S.; Hosoki, Y.; Ikuta, K.; Torimoto, Y.; Kohgo, Y. Upregulation of transferrin receptor 1 in chronic hepatitis C: Implication in excess hepatic iron accumulation. Hepatol. Res. 2005, 31, 203-210. [CrossRef] [PubMed]

110. Maiwall, R.; Kumar, S.; Chaudhary, A.K.; Maras, J.; Wani, Z.; Kumar, C.; Rastogi, A.; Bihari, C.; Vashisht, C.; Sarin, S.K. Serum ferritin predicts early mortality in patients with decompensated cirrhosis. J. Hepatol. 2014, 61, 43-50. [CrossRef] [PubMed]

111. Büyükasik, N.S.; Nadir, I.; Akin, F.E.; Cakal, B.; Kav, T.; Ersoy, O.; Buyukasik, Y. Serum iron parameters in cirrhosis and chronic hepatitis: Detailed description. Turk. J. Gastroenterol. 2011, 22, 606-611. [CrossRef] [PubMed]

112. Arain, S.A.; Kazi, T.G.; Afridi, H.I.; Talpur, F.N.; Mughal, M.A.; Shah, F.; Arian, S.S.; Panhwar, A.H. Estimation of copper and iron burden in biological samples of various stages of hepatitis $C$ and liver cirrhosis patients. Biol. Trace Elem. Res. 2014, 160, 197-205. [CrossRef] [PubMed]

113. Lin, C.C.; Huang, J.F.; Tsai, L.Y.; Huang, Y.L. Selenium, iron, copper, and zinc levels and copper-to-zinc ratios in serum of patients at different stages of viral hepatic diseases. Biol. Trace Elem. Res. 2006, 109, $15-24$. [CrossRef]

114. Nangliya, V.; Sharma, A.; Yadav, D.; Sunder, S.; Nijhawan, S.; Mishra, S. Study of trace elements in liver cirrhosis patients and their role in prognosis of disease. Biol. Trace Elem Res. 2015, 165, 35-40. [CrossRef] [PubMed]

115. Martinez-Peinado, M.; Rueda-Robles, A.; Nogueras-Lopez, F.; Villalon-Mir, M.; Oliveras-Lopez, M.J.; Navarro-Alarcon, M. Serum zinc and copper concentrations and ratios in cirrhotic patients: Correlation with severity index. Nutr. Hosp. 2018, 35, 627-632. [CrossRef] [PubMed] 
116. Zeng, D.W.; Dong, J.; Jiang, J.J.; Zhu, Y.Y.; Liu, Y.R. Ceruloplasmin, a reliable marker of fibrosis in chronic hepatitis B virus patients with normal or minimally raised alanine aminotransferase. World J. Gastroenterol. 2016, 22, 9586-9594. [CrossRef] [PubMed]

117. Marano, M.; Vespasiani Gentilucci, U.; Altamura, C.; Siotto, M.; Squitti, R.; Bucossi, S.; Quintiliani, L.; Migliore, S.; Greco, F.; Scarciolla, L.; et al. Altered metal metabolism in patients with HCV-related cirrhosis and hepatic encephalopathy. Metab. Brain Dis. 2015, 30, 1445-1452. [CrossRef] [PubMed]

118. Bao, B.; Prasad, A.S.; Beck, F.W.; Fitzgerald, J.T.; Snell, D.; Bao, G.W.; Singh, T.; Cardozo, L.J. Zinc decreases C-reactive protein, lipid peroxidation, and inflammatory cytokines in elderly subjects. Am. J. Clin. Nutr. 2010, 91, 1634-1641. [CrossRef] [PubMed]

119. Mikhail, T.H.; Nicola, W.G.; Ibrahim, K.H.; Salama, S.H.; Emam, M. Abnormal zinc and copper metabolism in hepatic steatosis. Boll. Chim. Farm. 1996, 135, 591-597. [PubMed]

120. Wong, V.S.; Wight, D.G.; Palmaer, C.R.; Alexander, G.J. Fibrosis and other histological features in chronic hepatitis C virus infection: A statistical model. J. Clin. Pathol. 1996, 49, 465-469. [CrossRef]

121. Brunt, E.M.; Janney, C.G.; Di Bisceglie, A.M.; Neuschwander-Tetri, A.A.; Bacon, B.R. Nonalcoholic steatohepatitis: A proposal for grading and staging the histological lesions. Am. J. Gastroenterol. 1999, 94, 2467-2474. [CrossRef] [PubMed]

122. Fartoux, L.; Poujol-Robert, A.; Guechot, J.; Wendum, D.; Poupon, R.; Serfaty, L. Insulin resistance is a cause of steatosis and fibrosis progression in chronic hepatitis C. Gut 2005, 54, 1003-1008. [CrossRef] [PubMed]

123. Toshimatsu, K.; Matsuura, B.; Ohkubo, I.; Niiya, T.; Furukawa, S.; Hiasa, Y.; Kawamura, M.; Ebihara, K.; Onji, M. Dietary habits and nutrient intake in non-alcoholic steatohepatitis. Nutrients 2007, 23, 46-52. [CrossRef] [PubMed]

124. Kang, X.; Zhong, W.; Liu, J.; Song, Z.; McClain, C.J.; Kang, Y.J.; Zhou, Z. Zinc supplementation reverses alcohol-induced steatosis in mice through reactivating hepatocyte nuclear factor- $4 \alpha$ and peroxisome proliferator-activated receptor- $\alpha$. Hepatology 2009, 50, 1241-1250. [CrossRef]

125. Misu, H.; Takamura, T.; Takayama, H.; Hayashi, H.; Matsuzawa-Nagata, N.; Kurita, S.; Ishikura, K.; Ando, H.; Takeshita, Y.; Ota, T.; et al. A liver-derived secretory protein, selenoprotein P, causes insulin resistance. Cell Metab. 2010, 12, 483-495. [CrossRef] [PubMed]

126. Nishina, S.; Korenaga, M.; Hidaka, I.; Shinozaki, A.; Sakai, A.; Gondo, T.; Tabuchi, M.; Kishi, F.; Hino, K. Hepatitis $\mathrm{C}$ virus protein and iron overload induce hepatic steatosis through the unfold protein response in mice. Liver Int. 2010, 30, 683-692. [CrossRef] [PubMed]

127. Tsuchiya, H.; Ebata, Y.; Sakabe, T.; Hama, S.; Kogure, K.; Shiota, G. High-fat, high fructose diet induces hepatic iron overload via a hepcidin-independent mechanism prior to the onset of liver steatosis and insulin resistance in mice. Metabolism 2013, 62, 62-69. [CrossRef]

128. Antonucci, L.; Porcu, C.; Iannucci, G.; Balsano, C.; Barbaro, B. Non-alcoholic fatty liver disease and nutritional implication: Special focus on copper. Nutrients 2017, 9, 1137. [CrossRef]

129. Kang, N.L.; Zhang, J.M.; Liu, Y.R.; Lin, S.; Dong, J.; Jiang, J.J.; Zhu, Y.Y.; Zeng, D.W. Novel predictive models using serum ceruloplasmin levels for hepatic steatosis in patients with chronic hepatitis C. Clin. Res. Hepatol. Gastroenterol. 2020, 44, 57-65. [CrossRef]

130. Song, M.; Schuschke, D.A.; Zhou, Z.; Chen, T.; Pierce Jr, W.M.; Wang, R.; Johnson, W.T.; McClain, C.J. High fructose feeding induces copper deficiency in Sprague-Dawley rats: A novel mechanism for obesity related fatty liver. J. Hepatol. 2012, 56, 433-440. [CrossRef]

131. Nose, Y.; Kim, B.E.; Thiele, D.J. Ctr1 derives intestinal copper absorption and is essential for growth, iron metabolism, and neonatal cardiac function. Cell Metab. 2006, 4, 235-244. [CrossRef] [PubMed]

132. Meenakshi-Sundaram, S.; Mahadevan, A.; Taly, A.B.; Arunodaya, G.R.; Swamy, H.S.; Shankar, S.K. Wilson's disease: A clinic-neuropathological autopsy study. J. Clin. Neurosci. 2008, 15, 409-417. [CrossRef] [PubMed]

133. Lalioti, V.; Sandoval, I.; Cassio, D.; Duclos-Vallee, J.C. Molecular pathology of Wilson's disease: A brief. J. Hepatol. 2010, 53, 1151-1153. [CrossRef]

134. Liggi, M.; Murgia, D.; Civolani, A.; Demelia, E.; Sorbello, O.; Demelia, L. The relationship between copper and steatosis in Wilson's disease. Clin. Res. Hepatol. Gastroenterol. 2013, 37, 36-40. [CrossRef]

135. Czaja, A.J.; Manns, M.P. Advances in the diagnosis, pathogenesis, and management of autoimmune hepatitis. Gastroenterology 2010, 139, 58-72. [CrossRef] [PubMed] 
136. Taubert, R.; Hardtke-Wolenski, M.; Noyan, F.; Lalanne, C.; Jonigk, D.; Schlue, J.; Krech, T.; Lichtinghagen, R.; Falk, C.S.; Scalaphoff, V.; et al. Hyperferritinemia and hypergammaglobulinemia predict the treatment response to standard therapy in autoimmune hepatitis. PLOS ONE 2017, 12, e0179074. [CrossRef] [PubMed]

137. Czaja, A.J. Review article: Iron disturbances in chronic liver diseases other than haemochromatosis-pathogenic, prognostic, and thepapeutic implications. Aliment. Pharmacol. 2019, 49, 681-701. [CrossRef]

138. Lyberopoulou, A.; Chachami, G.; Gatselis, N.K.; Kyratzopoulou, E.; Saitis, A.; Gabeta, S.; Eliades, P.; Praskeva, E.; Zachou, K.; Koukoulis, G.K.; et al. Low serum hepcidin in patients with autoimmune liver diseases. PLoS ONE 2015, 10, e0135486. [CrossRef]

139. Pereira, T.C.; Saron, M.L.; Carvalho, W.A.; Alves de Carvalho, W.; Vilena, M.M.; Hoehr, N.F.; Hessel, G. Research on zinc blood levels and nutritional status in adolescents with autoimmune hepatitis. Arq. Gastroenterol. 2011, 48, 62-65. [CrossRef]

140. Pemberton, P.W.; Aboutwerat, A.; Smith, A.; Burrows, P.C.; McMahon, R.F.T.; Warnes, T.W. Oxidant stress in type I autoimmune hepatitis: The link between necroinflammation and fibrogenesis? Biochim. Biophys. Acta 2004, 1689, 182-189. [CrossRef]

141. Sanna, A.; Firinu, D.; Zavattari, P.; Valera, P. Zinc status and autoimmunity: A systematic review and meta-analysis. Nutrients 2018, 10, 68. [CrossRef] [PubMed]

142. Rayman, M.P. Selenium and human health. Lancet 2012, 379, 1256-1268. [CrossRef]

143. Lleo, A.; Leung, P.S.C.; Hischfield, G.M.; Gershwin, E.M. The pathogenesis of primary biliary cholangitis: A comprehensive review. Semin. Liver Dis. 2020, 40, 34-48. [CrossRef] [PubMed]

144. Jain, S.; Scheuer, P.J.; Archer, B.; Newman, S.P.; Scherlock, S. Histological demonstration of copper and copper-associated protein in chronic liver diseases. J. Clin. Pathol. 1978, 31, 784-790. [CrossRef]

145. Salaspuro, M.P.; Sipponen, P.; Ikkala, E.; Kolho, L.; Makkonen, H.M.; Miettinen, T.A.; Räsänen, J.A.; Siurala, M. Clinical correlation and significance of orceinpositivity in chronic active hepatitis and primary biliary cirrhosis. Ann. Clin. Res. 1976, 8, 206-215. [PubMed]

146. Himoto, T.; Yoneyama, H.; Kurokochi, K.; Inukai, M.; Masugata, H.; Goda, F.; Haba, R.; Watanabe, S.; Senda, S.; Masaki, T. Contribution of zinc deficiency to insulin resistance in patients with primary biliary cirrhosis. Biol. Trace Elem. Res. 2011, 144, 133-142. [CrossRef]

147. Aboutwerat, A.; Pemberton, P.W.; Smith, A.; Burrows, P.C.; McMahon, R.F.T.; Jain, S.K.; Warnes, T.W. Oxidant stress is a significant feature of primary biliary cirrhosis. Biochim. Biophys. Acta 2003, 1637, 142-150. [CrossRef]

148. Romeo, S.; Kozlitina, J.; Xing, C.; Pertsemlidis, A.; Cox, A.; Pennacchio, L.A.; Boerwinkle, E.; Cohen, J.C.; Hobbs, H.H. Genetic variation in PNPLA3 confers susceptibility to nonalckholic fatty liver disease. Nat. Genet. 2008, 40, 1461-1465. [CrossRef]

149. Valenti, L.; Al-Serri, A.; Daly, A.K.; Galmozzi, E.; Rametta, R.; Dongiovanni, P.; Nobili, V.; Mozzi, E.; Roviaro, G.; Vanni, E.; et al. Homozygosity for the patatin-like phospholipase-3/adiponutrin 1148M polymorphism influences liver fibrosis in patients with nonalcoholic fatty liver disease. Hepatology 2010, 51, 1209-1217. [CrossRef]

150. Kawaguchi, T.; Sumida, Y.; Uemura, A.; Matsuo, K.; Takahashi, M.; Takamura, T.; Yasui, K.; Saibara, T.; Hashimoto, E.; Kawanaka, M.; et al. Genetic polymorphisms of the human PNPLA3 gene are strongly associated with severity of non-alcoholic fatty liver disease in Japanese. PLoS ONE 2012, 7, e38322. [CrossRef]

151. Stättermayer, A.F.; Traussnigg, S.; Dienes, H.P.; Eigner, E.; Stauber, R.; Lackner, K.; Hofer, H.; Stift, J.; Wrba, F.; Stadlmayr, A.; et al. Hepatic steatosis in Wilson Disease-Role of copper and PNPLA3 mutations. J. Hepatol. 2015, 63, 156-163. [CrossRef] [PubMed]

152. Yalcin, S.; Kayaalti, Z.; Söylemezoglu, T. Role of interleukin-6-174 G/C promoter polymorphism in trace metal levels of autopsy kidney and liver tissues. Int. J. Hyg. Environ. Health 2011, 214, 219-224. [CrossRef] [PubMed]

153. Rishi, P.; Kaur, P.; Virdi, J.S.; Shukla, G.; Koul, A. Amelioratory effects of zinc supplementation on Salmonella-induced hepatic damage in the murine model. Dig. Dis. Sci. 2008, 53, 1063-1070. [CrossRef] [PubMed]

154. Allali, I.; Arnold, J.W.; Roach, J.; Cadenas, M.B.; Buts, N.; Hassan, H.M.; Koci, M.; Ballou, A.; Mendoza, M.; Ali, R.; et al. A comparison of sequencing platforms and bioinformatics pipelines for compositional analysis of gut microbiome. BMC Microbiol. 2017, 17, 194. [CrossRef] [PubMed] 
155. Conrads, G.; Abdelbary, M.M.H. Challenges of next-generation sequencing targeting anaerobes. Anaerobe 2019, 58, 47-52. [CrossRef] [PubMed]

156. Usami, M.; Miyoshi, M.; Yamashita, H. Gut microbiota and host metabolism in liver cirrhosis. World J. Gastroenterol. 2015, 21, 11597-11608. [CrossRef]

157. Chen, D.; Le, T.H.; Shahidipour, H.; Read, S.A.; Ahlenstiel, G. The role of gut-derived microbial antigens on liver fibrosis initiation and progression. Cells 2019, 8, 1324. [CrossRef]

158. Scholz, R.L.; Greenberg, E.P. Sciality in Escherichia coli: Enterochelin is a private good at low cell density and can be shared at high cell density. J. Bacteriol. 2015, 197, 2122-2128. [CrossRef]

159. Iebba, V.; Guerrieri, F.; Di Gregorio, V.; Levrero, M.; Gagliardi, A.; Santangelo, F.; Sobolev, A.P.; Circi, S.; Giannelli, V.; Mannina, L.; et al. Combing amplicon sequencing and metabolomics in cirrhotic patients highlights distinctive microbiota features involved in bacterial translocation, systemic inflammation and hepatic encephalopathy. Sci. Rep. 2018, 8, 8210. [CrossRef]

160. Abu-Shanab, A.; Quigley, E.M.M. The role of the gut microbiota in nonalcoholic fatty liver disease. Nat. Rev. Gastroenterol. Hepatol. 2010, 7, 691-701. [CrossRef]

161. Song, M.; Li, X.; Zhang, X.; Shi, H.; Vos, M.B.; Wei, X.; Wang, Y.; Gao, H.; Rouchka, E.C.; Yin, X.; et al. Dietary copper-fructose interactions alter gut microbial activity in male rats. Am. J. Physiol. Gastrointest. Liver Physiol. 2018, 314, G119-G130. [CrossRef] [PubMed]

162. Cruz-Jentoft, A.J.; Baeyens, J.P.; Bauer, J.M.; Boirie, Y.; Cederholm, T.; Landi, F.; Martin, F.C.; Michel, J.P.; Rolland, Y.; Schneider, S.M.; et al. Sarcopenia; European consensus on definition and diagnosis: Report of the European Working Group on Sarcopenia in Older People. Age Ageing 2010, 39, 412-423. [CrossRef] [PubMed]

163. Himoto, T.; Miyatake, K.; Maeba, T.; Masaki, T. Verification of the nutritional and dietary factors associated with skeletal muscle index in Japanese patients with nonalcoholic fatty liver disease. Can. J. Gastroenterol. Hepatol. 2020. [CrossRef]

164. Ebadi, M.; Bhanji, R.A.; Mazurak, V.C.; Montano-Loza, A.J. Sarcopenia in cirrhosis: From pathogenesis to interventions. J. Gastroenterol. 2019, 54, 845-859. [CrossRef]

165. van Dronkelaar, C.; van Velzen, A.; Abdelrazek, M.; van der Steen, A.; Weijs, P.J.M.; Tieland, M. Minerals and sarcopenia; the role of calcium, magnesium, phosphorus, potassium, selenium, sodium, and zinc on muscle mass, muscle strength, and physical performance in older adults: A systemic review. J. Am. Med. Dir. Assoc. 2018, 19, 6-11. [CrossRef] [PubMed]

166. Zhao, G. Is iron accumulation a possible risk factor for sarcopenia? Biol. Trace Elem. Res. 2018, 186, $379-383$. [CrossRef]

167. Tkaczyszyn, M.; Drozd, M.; Wegrzynowska-Teodorczyk, K.; Flinta, I.; Kobak, K.; Banasiak, W.; Ponikowski, P.; Jankowska, E.A. Depleted iron stores are associated with inspiratory muscle weakness independently of skeletal muscle mass in men with systolic chronic heart failure. J. Cachexia Sarcopenia Muscle 2018, 9, 547-556. [CrossRef] [PubMed]

168. Nishikawa, H.; Enomoto, H.; Yoh, K.; Iwata, Y.; Sakai, Y.; Kishino, K.; Ikeda, N.; Takashima, T.; Aizawa, N.; Takata, R.; et al. Serum zinc concentration and sarcopenia: A close linkage in chronic liver diseases. J. Clin. Med. 2019, 8, 336. [CrossRef] [PubMed]

169. Grüngreiff, K. Branched amino acids and zinc in the nutrition of liver cirrhosis. J. Clin. Exp. Hepatol. 2018, 8, 480-483. [CrossRef] [PubMed]

170. Chen, Y.L.; Yang, K.C.; Chang, H.H.; Lee, L.T.; Lu, C.W.; Huang, K.C. Low serum selenium level is associated with low muscle mass in the community-dwelling elderly. J. Am. Med. Dir. Assoc. 2014, 15, 807-811. [CrossRef] [PubMed]

171. Wang, H.; Li, T.L.; Hsia, S.; Su, I.L.; Chan, Y.L.; Wu, C.J. Skeletal muscle atrophy is attenuated in tumor-bearing mice under chemotherapy by treatment with fish oil and selenium. Oncotarget 2015, 6, 7758-7773. [CrossRef] [PubMed]

172. Langley, B.; Thomas, M.; Bishop, A.; Sharma, M.; Gilmour, S.; Kambadur, R. Myostatin inhibits myoblast differentiation by down-regulating MyoD expression. J. Biol. Chem. 2002, 277, 49831-49840. [CrossRef] [PubMed]

173. O’Hara, S.P.; Mott, J.L.; Spinter, P.L.; Gores, G.J.; LaRusso, N.F. Micro RNAs: Key modulators of posttranscriptilnal gene expression. Gastroenterology 2009, 136, 17-25. [CrossRef] [PubMed] 
174. Bueno, M.J.; Perez de Castro, I.; Malumbres, M. Control of cell proliferation pathways by microRNAs. Cell Cycle 2008, 7, 3143-3148. [CrossRef] [PubMed]

175. Gjorgjieva, M.; Sobolewski, C.; Dolicka, D.; Correia de Sousa, M.; Foti, M. miRNA and NAFLD: From pathophysiology to therapy. Gut 2019, 68, 2065-2079. [CrossRef]

176. Shpyleva, S.; Pogribna, M.; Cozart, C.; Bryant, M.S.; Muskhelishvili, L.; Tryndyak, V.P.; Ross, S.A.; Beland, F.A.; Pogribny, I.P. Interstrain differences in the progression of nonalcoholic steatohepatitis to fibrosis in mice are associated with altered hepatic iron metabolism. J. Nutr. Biochem. 2014, 25, 1235-1242. [CrossRef] [PubMed]

(C) 2020 by the authors. Licensee MDPI, Basel, Switzerland. This article is an open access article distributed under the terms and conditions of the Creative Commons Attribution (CC BY) license (http://creativecommons.org/licenses/by/4.0/). 